\title{
Identification of Efficient Energy Source among Solar, Biomass and Battery for Electric Vehicle Charging using Novel Optimal Firefly Algorithm
}

Nishant Kumar ( $\square$ nishanthphd01@gmail.com )

National Institute of Technology Jamshedpur https://orcid.org/0000-0002-3869-1244

Kumari Namrata

National Institute of Technology Jamshedpur

\section{Research Article}

Keywords: Electric Vehicles, Renewable Energy Resources, Optimal Firefly Algorithm, Annual cost and Charging Stations

Posted Date: July 12th, 2021

DOI: https://doi.org/10.21203/rs.3.rs-665796/v1

License: (c) (i) This work is licensed under a Creative Commons Attribution 4.0 International License.

Read Full License 


\title{
Identification of Efficient Energy Source among Solar, Biomass and Battery for Electric Vehicle Charging using Novel Optimal Firefly Algorithm
}

\author{
$1^{*}$ Nishant Kumar, ${ }^{2}$ Kumari Namrata \\ ${ }^{1}$ Electrical Engineering, National Institute of Technology, Jamshedpur, Jharkhand. \\ ${ }^{2}$ Associate Professor, Electrical Engineering, National Institute of Technology, Jamshedpur, Jharkhand.
}

Corresponding Author's Mail ID: nishanthphd01@gmail.com

\begin{abstract}
-
Background: The EV (Electric Vehicles) is rapidly growing as a substitute to oil dependant vehicles to minimize the pollutant and greenhouse gas (GHS) emissions. Various charging schemes and grid integration techniques are introduced to minimize the impacts of EV charging. Hence, this study introduced a system that uses renewable energy sources (RES) like solar energy, biomass and battery for $\mathrm{EV}$ charging.
\end{abstract}

Objective: This study intended to calculate the cost of the system design as well as variations in its cost during the usage on an annual basis. In addition, it used various energy conversion technologies such as solar panel, battery and biomass to find the effective source of energy for EV charging through the proposed novel Optimal Firefly Algorithm (OFA).

Methodology: An initial setup is made that consists of number of buildings, overall load demand, ratings of EV charging, storage capacity, grid intake and solar panel. Then, the proposed novel OFA is used to find the count of EVs that gets charged from the charging stations and its choice of charging from the charging stations. The computation is performed on an annual basis for the cost, energy and count of EVs that arrive to the charging stations to get it charged. Results: The proposed methodology is used to compare the efficiency of the solar, biomass and battery efficiency in charging an EV through computation of Net present cost, Cost of Energy, EV savings and power generation. The results revealed that that the proposed system is effective than the traditional methods and effectively identified that the solar energy is the effective source for EV charging.

Keywords: Electric Vehicles, Renewable Energy Resources, Optimal Firefly Algorithm, Annual cost and Charging Stations.

\section{INTRODUCTION}

In recent years, the EV (Electric Vehicles) technology has developed rapidly due to various merits afforded by them. Moreover, the technological progressions in the EV charging need more investigation on this area and attempts for their deployment worldwide. This paper [1] affords a complete survey on the developing progressions in the rapid EV charging technologies, infrastructure as well as progressed international standards that possess a complete coverage of the issues identified and the chances offered. In spite of the environmental and economic merits, incorporation of EVs with the PG (Power Grid) can establish certain adverse influence on the current electricity network in accordance with the voltage deviations, power quality and network loading. Similarly, this study [2] surveyed the traditional technology corresponding to the fast EV charging with a complete research work coverage associated to the road blocks and challenges to be detected in its execution. Additionally, V2G (Vehicle to Grid) technology and its future scenario is discussed. Based on this discussion, it is summarized that it is essential to expand the fast EV charging environment for the merits of the manufacturers and users [3]. In addition, this article [4] intended to evaluate the influence of progressively enhancing $\mathrm{EV}$ shares in scenarios with varied production levels from the discontinuous renewable resources utilizing charging and technical tactics. The outcomes are compared in accordance with different indicators such as annual costs, $\mathrm{CO}_{2}$ emissions as well as RES curtailments. The enhancement of the RES power generation as well as oil powered transport vehicles with $\mathrm{EV}$ minimized the $\mathrm{CO}_{2}$ emissions by $20 \%$ in comparison to the $\mathrm{CO}_{2}$ emission level in 2015. Evaluating the real complete life cycle costs corresponding to EV from a socio economic and technical perspective need to be executed [5]. Similarly, this article [6] explores a concurrent ideal PV (Photovoltaic) placement and EVs in DS (Distributed System) for actual power loss minimization as well as voltage profile improvement. The optimal PV array allocation and EVs in DS is detected via ABC (Artificial Bee Colony) population on the basis of meta-heuristic optimization methodology. Additionally, doubtful demand of twenty four hours for individual bus is taken into account in this research. The blend of EVs placement and PV array exhibits effective outcomes in comparison to other conditions. The CCC (Convergence Characteristic Curve) of $\mathrm{ABC}$ algorithm represents that the algorithm has the ability to solve many complex optimization issues [7]. Moreover, this paper [8] considered a micro grid that is grid independent to assure the validity of the 
recommended optimal capacity planning technique and EMS (Energy Management Scheme). The outcomes attained from simulation revealed the efficiency of the proposed method by reducing the cost of the micro grid that is grid independent [9]. The recommended REM-GOA (Rule based Energy Management-Grasshopper Optimization Algorithm) is analyzed via a comparative study. The study reveals that the recommended algorithms affords effective outcomes [10]. Hence, this study introduced a novel Optimal Firefly Algorithm (OFA) to find the efficiency of solar energy, biomass or battery for charging an electric vehicle on an annual basis. The proposed methodology is evaluated to find its efficacy.

The major contributions of this study are listed below:

- To exploit various energy conversion technologies like PV (Photovoltaic) - solar panel, biomass and battery to find the efficient technology for EV charging through the proposed novel Optimal Firefly Algorithm (OFA).

- To find the cost of the system design and variations in cost of the energy for $\mathrm{EV}$ (Electric Vehicle) charging on an annual basis.

- To compare the proposed methodology with the existing methods to validate the efficiency of the proposed method than the existing method.

\subsection{Paper Organization}

The basic ideas about the EV charging is discussed in section I. The Section II explores the reviews of various existing works associated with this context. The proposed methodology is clearly explored in section III. The results obtained through the implementation of the proposed method are discussed in section IV. Finally, the overall view of the study is summarized in section $\mathrm{V}$.

\section{REVIEW OF EXISTING WORK}

This section presents the review of various existing works related to electric vehicle charging using renewable energy sources such as solar energy and biomass or battery. The various techniques involved in this process are briefly discussed below.

The speculative nature of RES and the load demand of EVs led to huge scale incorporation of these resources in the PS (Power Systems). It can pressure the consistent network performance like minimizing the power quality, enhancing power losses as well as voltage deviations. These issues must be mitigated through optimal planning on the basis of variable result from RES for satisfying the supplementary request instigated by EV charging. Hence, this study [11] introduced a technique for sizing and optical locating of EV and RES charging stations concurrently. In addition, management of vehicle charging stages has been afforded. A multi objective optimization issue has been outlined to attain objective variables so as to minimize the power losses, cost of the EV battery, voltage fluctuations, demand supplying and charging costs. In accordance to the outcomes, the sizing and optimal sitting of the RES as well as charging station of EVs enhance the voltage profile of the power systems through minimization of deviation in voltage in high loadedbus. The concurrent annual planning of generation resources as well as its scheduling have been taken into account to find the optimal-capacity and the generation resource types for MGs (Micro grids). This paper [12] introduced a multi objective model that comprises of various contradictory objective functions such as Energy Not Supplied (ENS), DRP (Demand Response Program), operational costs and pollution. This model has been solved via the $\varepsilon$ constraints technique and applying the EMA (Exchange Market Algorithm). The simulation outcomes reveal the influence of the types of generation resources on the operation cost, reliability, power loss and pollution in the MG. The introduced strategy will lead to a system with enhanced financial condition and cleaner production. In future, the investigators can review the influence of other generation resource kinds on this recommended model. Additionally, this proposed model could be investigated on the supplementary MGs so as to be examined. Furthermore, few facility and economic oriented drawbacks can be taken into account in the recommended strategy. Moreover, HRS (Hybrid Renewable System) is a kind of ESs (Energy Systems) that can be utilize as a DG (Distributed Generation) resources to minimize the network losses thereby enhancing its efficacy. The overall design stage consists of two main constraints such as availability and equipment cost. This article [13] considered these restraints and utilizing DGs as RES on the basis of multi objective PSO (Particle Swarm Optimization) has been used. Further, BB (Battery Bank) has been utilized as an energy storage and backup unit of the HS (Hybrid System) to minimize the RES volatility. The proposed strategy has been applied on a real world case and evaluated its efficiency. The proposed technique has been compared with the multi objective GA (Genetic Algorithm). The simulation outcomes revealed that the recommended technique exhibited efficient outcome thereby minimizing costs and enhancing availability [14].

On the other hand, this article [15] aimed to attain a techno economic plan of an off grid hybrid system consisting of PV or bio-gas generator or battery 
system with the assistance of meta-heuristic optimization methods for a RTS (Radio Transmitter Station) in India. Two such methodologies such as MFO (Moth Flame Optimization) and WCA (Water Cycle Algorithm) that have gained popularity recently have been evaluated by comparing it with GA. Further work involved a comparative analysis where meta-heuristic algorithms and HRES (Hybrid Renewable Energy System) have been compared with one another to improve the knowledge base in solving the optimization issues corresponding to HRES by utilizing these methodologies [16]. Accordingly, this study [17] explored few research gaps in this context that have to be addressed further. Enhancing the PV (Photovoltaic) power production RR (Ramp Rate) modelling and quantifying the collective CSI (Clear Sky Index) on a city-scale have been the main concern for PV research. Variations in the model assumptions namely charging profiles, charging powers and charging locations have to be researched extensively for the EV charging LMs (Load Models). Besides, there exists an immediate requirement for measuring the charging station load. This is vital in enhancing the time series prediction and accurate model methodologies [18]. Moreover, this study [19] recommended a REMS (Rule based Energy Management Scheme) for EV charging from PV grid system. This scheme affords an uninterrupted charging in daytime with a constant cost. As this scheme is only for PV-integrated charging system, this work has to be extended and can incorporate supplementary RE (Renewable Energy) sources like tidal, biomass and wind [20]. In addition, this study [21] optimized the functionality of V2G technology in the Distribution Grid. Moreover, the optimization programming has to be introduced to reduce the network's operational cost. The proposed model optimally used the V2G technology for scheduling the EV charging station. The simulation has to be carried out within a shorter period in near future [22]. On the other hand, BFGEs (Feeding Biomass Fuelled Gas Engines) affords chances to minimize the usage of fossil fuels in electricity generation and in vehicles. This paper [23] needed the usage of BFGE stochastic model and loads of EV charging appropriate for probabilistic research.

The accessibility of huge statistical data for the proposed model in functioning RDS (Radial Distribution System) afforded useful perceptions and resulted in fascinating results. Thus, many EV charging loads have to be connected to RDS. Hence, actions have to be undertaken in RDSs for maintenance of voltage constraints [24]. In addition, there exists a demand for the TS (Transportation Sector) to fulfil the international and national targets for GHG (Green House Gas) emission minimization, reducing the impacts of air pollution on human health, improve the economy through transformation from ICEV (Internal Combustion Engine Vehicles) and minimize the fossil fuel dependency. Hence, this article [25] represented the possible influence of progressive trucking on the supply of biomass feedstock. It has been found that the influence of progressive trucking will consist of other fields such as goods transportation that assists the industry development. Additionally, this study [26] proposed a MILP (Mixed Integer Linear Programming) design optimization and operation outline for a supply chain of electricity for EVs and the remaining economic areas in a country or state. The outcomes exhibited that the contribution of electricity based on fossil fuels decreased from eight five percent to sixty eight percent. The recommended CSN (Charging Station Network) comprises of 12820 charging-points. It consisted of AC chargers that have the capacity $22 \mathrm{KW}$. Thus, it has been found that the combination of EV and ecofriendly power generation is an appropriate substitute to stop the transportation emission paths. In addition, this paper [27] adhere to the goals for the sustainable development of USA and examined the influence of energy consumption through biomass, fossil fuel as well as the economic development on the $\mathrm{CO}_{2}$ emissions in the TS of USA. The outcomes of this research represent that the policy-makers must set objectives for introducing varied sustainable transportation choices. This study [28] should examine the efficiency of alternating the vehicle technologies with eco-friendly technologies like EVs, PHEVs (Plug-in Hybrid EVs), BEVs (Battery EVs) as well as HEVs (Hybrid EVs). This study presented a survey about the present situation about the EV market, charging infrastructure, its standards as well as the influence of the EV charging on the micro grid. The study explored the present EV status. It also affords a complete study on the significant grid interconnection and EV charging standards. Various infrastructure configurations in accordance with communication and control architectures have been studied and assessed. The EP (Electric Power) market has been studied by taking the EV owners and aggregators into account. It also surveyed the various game and optimization based methodologies for integration management of EV grid. Similarly, this study [29] finds the optimal sizing as well as cost minimization of RER (Renewable Energy Resources) integrated with grid by utilizing the dragonfly algorithm. This study intended to minimize the annual power cost with minimum solar panels. This proposed method has been compared with the existing $\mathrm{ABC}$ algorithm. The results of the recommended methodology confirmed that the system connected with grid with an optimal count of components satisfied the needs with minimum cost. Simulation has been undertaken in a MATLAB environment. The comparative analysis revealed that the proposed system is better than the existing 
method. The proposed methodology can be employed to supplementary resources, update research techniques where cost computation is found through algorithms [30].

\section{PROPOSED METHODOLOGY}

The proposed novel optimal firefly algorithm (OFA) is used to find the efficient energy sources among solar, biomass and battery to charge an EV. The proposed methodology calculates the cost and energy associated with each energy sources to charge an EV on an annual basis. In addition, the number of vehicles entering the charging stations are calculated for a year. The overall view of the proposed system is shown in the below figure.1.

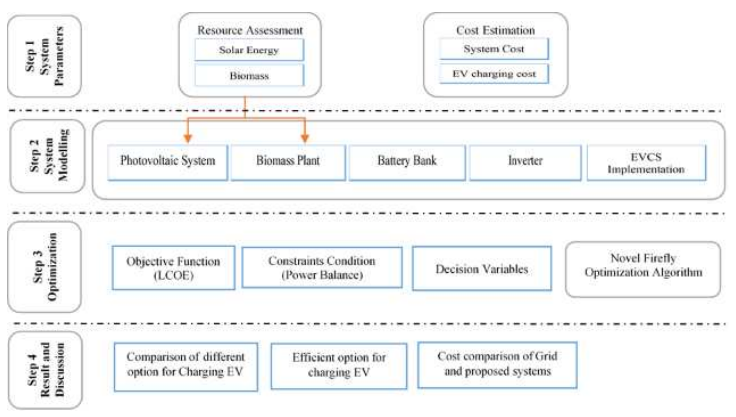

Figure.1. Overall view of the proposed system

Initially, the hybrid renewable energy sources (solar, biomass and battery (if needed)) is setup. The battery is taken as a source but is utilized only when there is a deficient in energy. Solar and biomass are the renewable sources that are taken into account for charging an EV. The yearly load of EVCS (Electric Vehicle Charging Station) is estimated by optimal firefly algorithm. Then, the component selection is performed. Subsequently, the cost and size required for EVCS is determined. After this, the designed model is analysed by simulation software tool. The Then, the energy and cost is initialized. After this process, the power output from the RES (Renewable Energy Sources) is computed. The initialization process includes the number of buildings (the number of charging stations), overall load demand on daily and hourly basis, the ratings of $\mathrm{EV}$ charging, storage capacity, solar panel (each of 250 WP) and grid intake. Here the charging stations are considered as buildings and each building has a solar panels, biomass and battery to charge an EV. Subsequently, the proposed novel OFA (Optimal Firefly Algorithm) is used to calculate the energy sources (solar energy, biomass or battery) taken by each EV for charging on the basis of certain conditions as mentioned in the above figure.1. Finally, the efficient energy source is determined for charging an EV on the basis of the computations.

\subsection{Novel Optimal Firefly Algorithm (OFA)}

The Optimal Firefly Algorithm (OFA) is a Meta heuristic optimization methodology that relies on the fascinating light flashing manners made by the bioluminescence of few firefly species. Various recurring patterns of light flashes are utilized to interact for mating and also to attract the possible prey. As a rule, it is stated that only a single firefly gets attracted to other fireflies ignoring sex as fireflies are unisexual. The rule also states that the most attractive firefly has more brightness as these two are directly proportional. The firefly that possess minimum brightness will be headed for the brighter firefly. This is because both the flashing firefly's movement is taken into account. If there is no fireflies having similar brightness, then their movement is taken as random in the SS (Search Space). The landscape corresponding to the OF (Objective Function) finds the firefly's brightness. The pseudo code of the proposed novel OFA is given below.

\begin{tabular}{|l|}
\hline Pseudo code I: Optimal Firefly Algorithm \\
\hline Step 1: Objective function is given by $\mathrm{f}(\mathrm{x}), x=$ \\
$\left(A 1, \ldots \ldots \ldots A_{d}\right)^{T}$ \\
Step 2: Generate the preliminary fireflies \\
population $X_{n}(n=1 \ldots \ldots \ldots \ldots \ldots i)$ \\
Step 3: The intensity of light $I_{n}$ at $X_{n}$ is found by \\
$f\left(X_{n}\right)$ \\
Step 4: Describe the light-absorption coefficient \\
$\alpha$ \\
While $(N<$ max Generation $)$ \\
For $n=1 ; i$ all $i$ fireflies \\
For $k=1 ; n$ all $i$ fireflies \\
If $\left(W_{k}>W_{n}\right)$, many firefly $n$ towards $k$ in $d-$ \\
dimension; \\
End if \\
Step 5: Attractiveness differs with distance $d$ \\
through $d-d i m e n s i o n$ and exp[- $\alpha d]$; \\
End if \\
Step 6: Estimate the new result and update the \\
intensity of light \\
End for $k$ \\
End for $n$ \\
Step 7: Rank the results and determine the \\
present best firefly. \\
End while \\
Post the process outcome as well as visualization \\
\hline
\end{tabular}

The application of the proposed novel OFA in solving the framed design issues of the energy system includes several steps as mentioned in the above pseudo code. Initially, the objective function is considered. Then, the preliminary firefly's population is generated and the intensity of the light is found for individual firefly through the use of the objective function. Subsequently, the light absorption coefficient $\alpha$ is defined. After this, the new results are estimated and the intensity of the light is updated. Finally, the results are ranked and the present best firefly is determined. 
The study introduced a proposed novel OFA to compute various parameters to find the efficient source for charging of EV. The various parameters involved in this process are briefly discussed below:

\section{A. Size of Solar Panel}

The size of solar panel is computed by the below equation.1.

$\mathrm{P}_{\mathrm{SPV}}=\mathrm{H}_{\mathrm{T}} * \mathrm{~A}_{\mathrm{SPV}} * \eta_{\mathrm{spv}}$

Here, $A_{S P V}$ denotes the area of solar photovoltaic (SPV) panel, $\mathrm{H}_{\mathrm{T}}$ denotes the solar radiation in $\mathrm{KW} / \mathrm{m}^{2}$ and $\eta_{\mathrm{spv}}$ represents the SPV panel efficiency.

\section{B. Biomass Power-Calculation}

The biomass power is computed through the below equation. 2 .

$\mathrm{P}_{\mathrm{BMG}}=\frac{{ }_{\mathrm{BM}}(\text { ton } / \mathrm{yr}) * \mathrm{CV}_{\mathrm{BM}} * \eta_{\mathrm{BM}} * 1000}{365 * 860 *(\text { operating hours per day })}$

Here ${ }^{\delta}{ }_{\text {BM }}$ denotes the total fuel-wood, $P_{B M G}$ represents the power output corresponding to the biomass generator, $\eta_{\mathrm{BM}}$ indicates the total efficiency in energy-conversion and $\mathrm{CV}_{\mathrm{BM}}$ indicates the biomass calorific value.

\section{Battery-Storage System}

The accessibility of RES cannot be predicted. Thus, the Battery-Storage System is incorporated in the Integrated Renewable Energy (IRE) system. The solar and biomass is a DC (Direct Current) and hence it needs a bi-directional convertor. The BB (Battery Bank) should be allowed to discharge in accordance with the DOD (Depth of Discharge). It is expressed by the below equation. 3 .

$\mathrm{C}_{\text {min }}=\mathrm{DOD} * \mathrm{C}_{\mathrm{b}}$

Here DOD means Depth of Discharge, $\mathrm{C}_{\mathrm{b}}$ denotes the capacity of the BB.

In addition, the SOC (State of Charge) charging process is given by the below equation. 4 .

$$
\begin{aligned}
& \operatorname{SOC}(\mathrm{t}+1)=\operatorname{SOC}(\mathrm{t}) *(1-\sigma)+\left(\left(\operatorname{EP}_{\mathrm{DC}}(\mathrm{t})\right)+\right. \\
& \left.\mathrm{EP}_{\mathrm{AC}}(\mathrm{t}) * \eta_{\text {rect }}-\mathrm{P}_{\mathrm{LD}}(\mathrm{t})\right) * \eta_{\mathrm{BC}}
\end{aligned}
$$

Here SOC $_{\max }$ takes the nominal capacity value of the BB. In contrary, the SOC discharging process is given by the below equation. 5 .

$$
\begin{aligned}
& \operatorname{SOC}(\mathrm{t}+1)=\operatorname{SOC}(\mathrm{t}) *(1-\sigma)-\left(\mathrm{NP}_{\mathrm{AC}}(\mathrm{t}) *\right. \\
& \left.\eta_{\text {inv }}\right) / \eta_{\mathrm{DB}}
\end{aligned}
$$

The NPC (Net Present Cost) is determined as an efficient indicator as it consists of the overall costs that arises within the lifetime of the project. The TNPC (Total Net Present Cost) consists of initial capital cost, maintenance costs, replacement costs, fuel costs as well as investment appliance costs. Hence, reduction of TNPC is taken into account as a cost effective indicator for the FF (Fitness Function) for the recommended system. It is given by the below equation.5.

$\mathrm{T}_{\mathrm{NPC}}=\mathrm{C}_{\mathrm{NPV}}+\mathrm{OM}_{\mathrm{NPV}}+\mathrm{R}_{\mathrm{NPV}}+\mathrm{FC}_{\mathrm{NPV}}$

Here C indicates the Capital cost, OM represents the Operation Maintenance cost, $\mathrm{R}$ represents the replacement cost, FC denotes the Fuel Cost and NPV denotes the Net Present Value corresponding to the system component.

\section{E. Net Present Cost - NPC}

The total net present cost corresponding to the system component is computed by the use of the cost function equation as shown in equation. 7 .

$$
\begin{aligned}
& \mathrm{C}_{\mathrm{NPV}}=\left[\left(\alpha_{\mathrm{SPV}} * \mathrm{~N}_{\mathrm{SPV}}+\alpha_{\mathrm{BATT}} * \mathrm{~N}_{\mathrm{BATT}}+\alpha_{\mathrm{INV}} * \mathrm{P}_{\mathrm{INV}}+\right.\right. \\
& \left.\left.\alpha_{\mathrm{BGG}} * \mathrm{P}_{\mathrm{BGG}}\right)\right]
\end{aligned}
$$

Here $\alpha$ denotes the capital cost of each resources utilized, $\mathrm{N}$ is the number of generators utilized and $\mathrm{P}$ is the power outcome of the specified resources.

\section{F. Net Present Replacement Cost-NPRC}

The lifetime of the remaining equipment are higher than solar and battery, replacement occurs often. Thus, the replacement charge is included only for battery and inverter. The count of times it have to be replaced is computed by the below equation. 8 .

$\mathrm{X}_{\mathrm{b}}=\frac{\mathrm{N}}{\mathrm{L}_{\mathrm{B}}}-1$

The TNRC (Total Net Replacement Cost) corresponding to the system components is computed using the below cost function given by equation.9.

$\mathrm{R}_{\mathrm{NPV}}=\alpha_{\text {BATT }} * \mathrm{~N}_{\text {BATT }} \sum_{\mathrm{j}=5,10,15}\left(\frac{1+\mu}{1+\mathrm{i}}\right)^{\mathrm{j}}+\alpha_{\text {INV }} *$ $\mathrm{P}_{\text {INV }}\left(\frac{1+\mu}{1+\mathrm{i}}\right)^{10}$

Here $X_{b}$ denotes the count of times the inverter or battery requires to be replaced, $\mu$ represents the inflation (escalation rate - \%), $\mathrm{N}$ denotes the project lifespan, $\mathrm{L}_{\mathrm{b}}$ indicates the life of inverter or battery and I indicates the interest rate.

\section{G. Net Present Operation as well as Maintenance Costs}

The operation as well as maintenance cost is computed on the basis of initial maintenance cost

\section{Objective Function}


corresponding to each components. When the price increases in accordance with an annual rate of $\mu$, it can be computed by the below equation. 10 .

$0 \& \mathrm{M}_{\mathrm{NPV}}=\left[\left(\beta_{\mathrm{SPV}} * \mathrm{~N}_{\mathrm{SPV}}+\beta_{\mathrm{BATT}} *\right.\right.$

$\left.\left.\mathrm{N}_{\mathrm{BATT}}+\beta_{\mathrm{INV}} * \mathrm{P}_{\mathrm{INV}}++\beta_{\mathrm{BGG}} * \mathrm{P}_{\mathrm{BGG}}\right)\right] *$

$\sum_{j=1}^{n}\left(\frac{1+\mu}{1+i}\right)^{j}$

Here $\beta$ denotes the initial maintenance cost.

\section{H. Net Present Fuel Costs}

The fuel costs is completely for the biomass as it holds small quantity of fuel for its collection as well as conversion cost. This cost can be computed by the below equation. 11 .

$\mathrm{FC}_{\mathrm{NPV}}=\sum_{\mathrm{j}=1}^{\mathrm{n}}\left(\frac{1+\mu}{1+\mathrm{i}}\right)^{\mathrm{j}}\left\{\lambda_{\mathrm{AFR}}\left[\mathrm{FW}_{\mathrm{BGG}}\right]\right\}$

Here $\lambda_{\mathrm{AFR}}$ denotes the average fuel price of biomass (\$/ton) and FW $\mathrm{BGG}_{\mathrm{BG}}$ denotes the Food-Waste (ton/year).

\section{Cost of Energy - COE}

The COE corresponding to the IRE system is computed on the basis of TNPC as well as the energy generated. It is given by the below equation. 12 .

$\operatorname{COE}(\mathrm{Rs} / \mathrm{kWh})=\frac{\mathrm{TNPC} * \operatorname{CRF}(\mathrm{Y}, \tau)}{\sum_{\mathrm{t}=1}^{8760} \mathrm{E}_{\mathrm{GEN}}(\mathrm{t})}$

Here $\tau$ denotes the project life span, $\Upsilon$ indicates the interest rate annually, $\mathrm{E}_{\mathrm{GEN}}$ denotes the overall annual energy generated by the IRE system, TNPC indicates the Total Net Present Cost and CRF means Capacity Recovery Factor.

\section{RESULTS AND DISCUSSION}

The results obtained through the implementation of the proposed novel OFA in Simulink to find the efficient energy source (solar, biomass or battery) for $\mathrm{EV}$ charging is discussed in this section. In addition, the various computations are performed in terms of cost and energy on an annual basis is also explored here.

\subsection{Experimental Design}

The cost associated with the solar panel, battery and biomass is briefly discussed in the below figure. 2 .

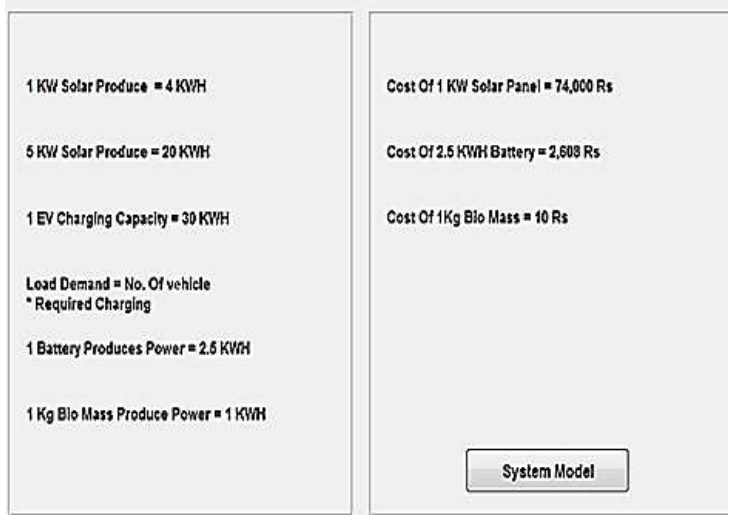

Figure.2. Cost estimation of solar panel, battery and biomass

From the above figure.2, it is found that $1 \mathrm{KW}$ solar produce $4 \mathrm{KWH}, 5 \mathrm{KW}$ solar produce $20 \mathrm{KWH}$, the charging capacity of one electric vehicle is $30 \mathrm{KWH}$, and load demand is computed as the product of the count of vehicles and required charging. One battery produces power at a rate of $2.5 \mathrm{KWH}, 1 \mathrm{Kg}$ biomass produces power of $1 \mathrm{KWH}$. Hence the overall cost of $1 \mathrm{KW}$ solar panel is 74000 rupees, cost of $2.5 \mathrm{KWH}$ battery is 2608 rupees and cost of one $\mathrm{kg}$ biomass in ten rupees. Hence, this reveals that biomass costs less whereas solar panel and battery costs more for initial setup.

The main system of power generation building model is given in the below figure.3. The solar panel, biomass and battery is integrated within each charging stations (here it is described as buildings) as shown in the below figure. 3 .

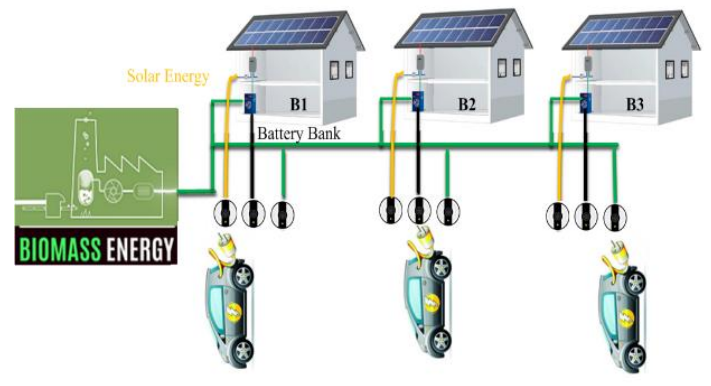

Figure.3. Main system of power generation building model

The EV gets charged from the solar energy of the solar panel, biomass or battery on the basis of its availability. The battery is used only when both of the other sources are insufficient in charging an EV.

Moreover, the solar power generation in $\mathrm{KWH}$ is given in the below figure. 4 . 


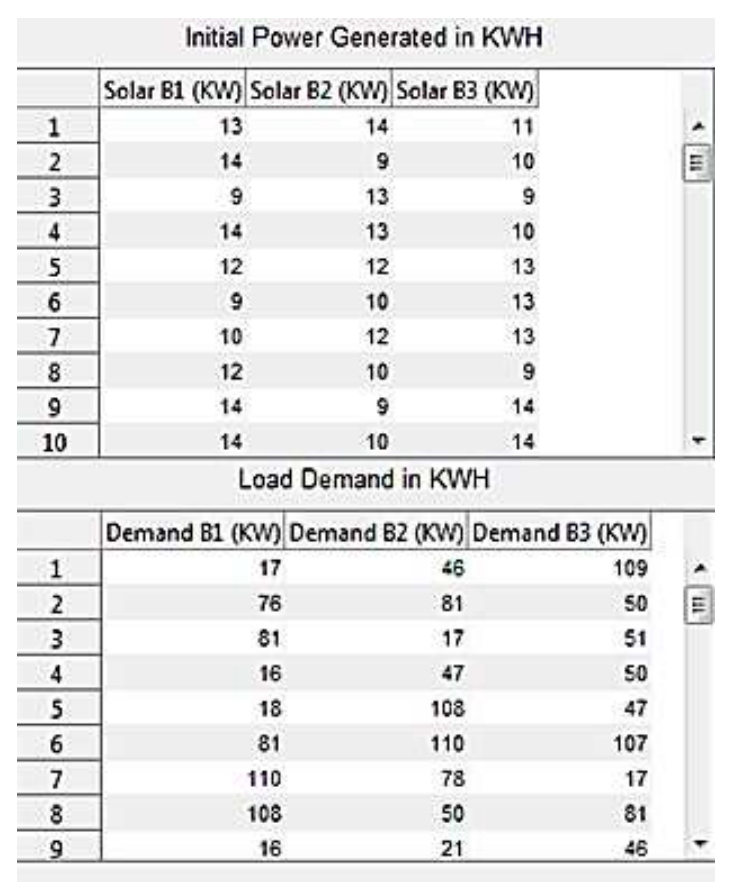

Figure.4. Initial power generation of solar energy and load demand in $\mathrm{KWH}$

The solar power generation from buildings B1, B2 and $\mathrm{B} 3$ is given in the above figure.4. In addition, the load demand in $\mathrm{KWH}$ is provided for the three buildings in the above figure. It is found that the solar power generation (SPG) varies in each buildings based on its availability for charging an EV.

Moreover, the required load and number of solar panel are given in the below figure.5.

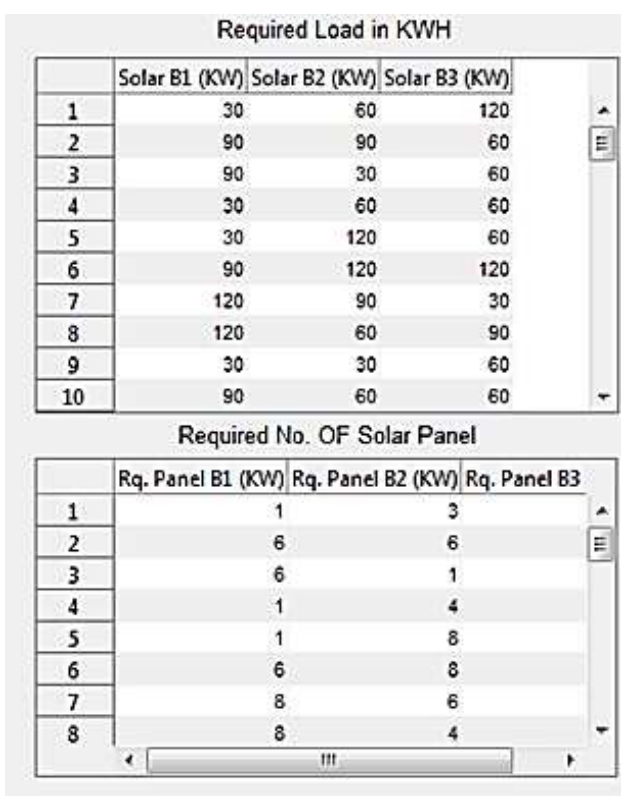

Figure.5. Required load and number of solar panel
The required load in $\mathrm{KWH}$ is calculated for each buildings B1, B2 and B3 which is shown in the above figure.5. Additionally, the required number of solar panel in each of the three buildings for charging an EV is calculated which is also shown in the above figure.5.

The solar energy generation for the three buildings on an annual basis is computed as shown in the below table.1.

Table-1. Computation of solar energy generation on an annual basis

\begin{tabular}{|c|c|c|}
\hline Solar (B1) & Solar (B2) & Solar (B3) \\
\hline 13 & 14 & 11 \\
\hline 14 & 9 & 10 \\
\hline 9 & 13 & 9 \\
\hline 14 & 13 & 10 \\
\hline 12 & 12 & 13 \\
\hline 9 & 10 & 13 \\
\hline 10 & 12 & 13 \\
\hline 12 & 10 & 9 \\
\hline 14 & 9 & 14 \\
\hline 14 & 10 & 14 \\
\hline 9 & 14 & 13 \\
\hline 14 & 9 & 9 \\
\hline 14 & 10 & 11 \\
\hline 11 & 9 & 13 \\
\hline 13 & 11 & 13 \\
\hline 9 & 9 & 10 \\
\hline 11 & 14 & 10 \\
\hline 14 & 10 & 13 \\
\hline 13 & 9 & 11 \\
\hline 14 & 10 & 12 \\
\hline 12 & 11 & 10 \\
\hline 9 & 9 & 10 \\
\hline 14 & 14 & 13 \\
\hline 14 & 10 & 13 \\
\hline 13 & 10 & 14 \\
\hline 13 & 9 & 9 \\
\hline 13 & 10 & 10 \\
\hline 11 & 9 & 9 \\
\hline 12 & 12 & 11 \\
\hline 10 & 13 & 10 \\
\hline 13 & 12 & 14 \\
\hline 9 & 9 & 9 \\
\hline 10 & 9 & 9 \\
\hline
\end{tabular}




\begin{tabular}{|c|c|c|}
\hline 9 & 13 & 12 \\
\hline 9 & 14 & 13 \\
\hline 13 & 12 & 10 \\
\hline 13 & 9 & 10 \\
\hline 10 & 13 & 11 \\
\hline 14 & 11 & 10 \\
\hline 9 & 10 & 12 \\
\hline 11 & 13 & 14 \\
\hline 11 & 9 & 12 \\
\hline 13 & 9 & 9 \\
\hline 13 & 13 & 11 \\
\hline 10 & 12 & 9 \\
\hline 11 & 12 & 12 \\
\hline 11 & 13 & 11 \\
\hline 12 & 13 & 14 \\
\hline 13 & 13 & 13 \\
\hline 13 & 10 & 11 \\
\hline 10 & 13 & 14 \\
\hline 13 & 12 & 9 \\
\hline 12 & 11 & 11 \\
\hline 9 & 9 & 14 \\
\hline 9 & 13 & 14 \\
\hline 11 & 11 & 13 \\
\hline 14 & 12 & 12 \\
\hline 11 & 13 & 11 \\
\hline 12 & 9 & 14 \\
\hline 10 & 9 & 9 \\
\hline 13 & 12 & 13 \\
\hline 10 & 11 & 12 \\
\hline 12 & 14 & 13 \\
\hline 13 & 13 & 11 \\
\hline 14 & 13 & 13 \\
\hline 14 & 9 & 14 \\
\hline 12 & 9 & 10 \\
\hline 9 & 9 & 12 \\
\hline 9 & 13 & 14 \\
\hline 10 & 14 & 12 \\
\hline 14 & 13 & 10 \\
\hline 10 & 9 & 12 \\
\hline 13 & 13 & 11 \\
\hline 10 & 9 & 13 \\
\hline 14 & 9 & 11 \\
\hline 11 & 12 & 11 \\
\hline 10 & 10 & 13 \\
\hline
\end{tabular}

\begin{tabular}{|c|c|c|}
\hline 10 & 12 & 14 \\
\hline 12 & 13 & 10 \\
\hline 11 & 12 & 14 \\
\hline 11 & 13 & 13 \\
\hline 13 & 10 & 14 \\
\hline 12 & 13 & 9 \\
\hline 12 & 14 & 11 \\
\hline 14 & 14 & 12 \\
\hline 10 & 9 & 10 \\
\hline 13 & 11 & 10 \\
\hline 13 & 11 & 13 \\
\hline 11 & 13 & 12 \\
\hline 12 & 12 & 12 \\
\hline 9 & 13 & 12 \\
\hline 9 & 11 & 9 \\
\hline 12 & 10 & 11 \\
\hline 13 & 9 & 11 \\
\hline 14 & 13 & 10 \\
\hline 9 & 10 & 13 \\
\hline 12 & 11 & 14 \\
\hline 11 & 12 & 10 \\
\hline 9 & 10 & 13 \\
\hline 11 & 12 & 9 \\
\hline 9 & 11 & 14 \\
\hline 13 & 9 & 9 \\
\hline 10 & 13 & 12 \\
\hline 12 & 9 & 11 \\
\hline 9 & 10 & 13 \\
\hline 12 & 10 & 12 \\
\hline 10 & 12 & 11 \\
\hline 12 & 9 & 14 \\
\hline 13 & 11 & 11 \\
\hline 13 & 9 & 11 \\
\hline 11 & 9 & 14 \\
\hline 9 & 13 & 9 \\
\hline 10 & 10 & 14 \\
\hline 14 & 12 & 10 \\
\hline 9 & 14 & 13 \\
\hline 13 & 11 & 12 \\
\hline 12 & 13 & 13 \\
\hline 14 & 13 & 11 \\
\hline 9 & 11 & 12 \\
\hline 11 & 12 & 13 \\
\hline 9 & 9 & 9 \\
\hline
\end{tabular}




\begin{tabular}{|c|c|c|}
\hline 14 & 14 & 9 \\
\hline 9 & 10 & 14 \\
\hline 13 & 10 & 12 \\
\hline 13 & 13 & 10 \\
\hline 14 & 11 & 11 \\
\hline 9 & 13 & 9 \\
\hline 11 & 11 & 10 \\
\hline 10 & 10 & 10 \\
\hline 13 & 9 & 10 \\
\hline 11 & 13 & 9 \\
\hline 14 & 11 & 11 \\
\hline 10 & 11 & 9 \\
\hline 10 & 12 & 14 \\
\hline 9 & 9 & 9 \\
\hline 9 & 10 & 14 \\
\hline 14 & 13 & 11 \\
\hline 12 & 13 & 9 \\
\hline 12 & 9 & 11 \\
\hline 9 & 9 & 13 \\
\hline 14 & 9 & 13 \\
\hline 12 & 9 & 12 \\
\hline 11 & 11 & 13 \\
\hline 12 & 12 & 14 \\
\hline 11 & 13 & 9 \\
\hline 9 & 12 & 10 \\
\hline 10 & 9 & 9 \\
\hline 9 & 12 & 10 \\
\hline 10 & 9 & 13 \\
\hline 10 & 9 & 13 \\
\hline 11 & 9 & 14 \\
\hline 9 & 9 & 12 \\
\hline 14 & 10 & 9 \\
\hline 14 & 10 & 14 \\
\hline 11 & 10 & 13 \\
\hline 11 & 10 & 10 \\
\hline 11 & 10 & 12 \\
\hline 14 & 10 & 14 \\
\hline 11 & 14 & 13 \\
\hline 9 & 13 & 14 \\
\hline 13 & 12 & 11 \\
\hline 11 & 10 & 11 \\
\hline 10 & 10 & 12 \\
\hline 11 & 9 & 10 \\
\hline 9 & 14 & 13 \\
\hline
\end{tabular}

\begin{tabular}{|c|c|c|}
\hline 9 & 13 & 12 \\
\hline 14 & 12 & 12 \\
\hline 14 & 10 & 10 \\
\hline 12 & 9 & 9 \\
\hline 9 & 12 & 11 \\
\hline 10 & 14 & 11 \\
\hline 11 & 10 & 13 \\
\hline 13 & 10 & 13 \\
\hline 9 & 11 & 13 \\
\hline 9 & 9 & 9 \\
\hline 10 & 13 & 9 \\
\hline 12 & 11 & 12 \\
\hline 13 & 14 & 10 \\
\hline 12 & 11 & 14 \\
\hline 11 & 12 & 14 \\
\hline 12 & 9 & 10 \\
\hline 10 & 11 & 13 \\
\hline 13 & 9 & 14 \\
\hline 10 & 13 & 12 \\
\hline 13 & 14 & 14 \\
\hline 10 & 11 & 14 \\
\hline 11 & 13 & 12 \\
\hline 12 & 10 & 13 \\
\hline 13 & 12 & 12 \\
\hline 9 & 13 & 9 \\
\hline 14 & 12 & 11 \\
\hline 13 & 11 & 12 \\
\hline 11 & 10 & 12 \\
\hline 11 & 11 & 11 \\
\hline 11 & 11 & 14 \\
\hline 10 & 11 & 13 \\
\hline 12 & 12 & 14 \\
\hline 12 & 13 & 11 \\
\hline 13 & 11 & 12 \\
\hline 13 & 11 & 14 \\
\hline 12 & 9 & 14 \\
\hline 11 & 9 & 13 \\
\hline 13 & 10 & 10 \\
\hline 12 & 10 & 12 \\
\hline 11 & 12 & 9 \\
\hline 14 & 14 & 11 \\
\hline 14 & 14 & 13 \\
\hline 12 & 11 & 14 \\
\hline 12 & 10 & 13 \\
\hline
\end{tabular}




\begin{tabular}{|c|c|c|}
\hline 12 & 13 & 11 \\
\hline 10 & 13 & 13 \\
\hline 10 & 13 & 11 \\
\hline 11 & 13 & 14 \\
\hline 10 & 9 & 14 \\
\hline 14 & 13 & 14 \\
\hline 10 & 11 & 11 \\
\hline 10 & 10 & 11 \\
\hline 10 & 9 & 10 \\
\hline 10 & 13 & 13 \\
\hline 11 & 10 & 14 \\
\hline 10 & 9 & 14 \\
\hline 14 & 12 & 12 \\
\hline 11 & 14 & 12 \\
\hline 10 & 12 & 9 \\
\hline 14 & 13 & 14 \\
\hline 14 & 9 & 11 \\
\hline 11 & 14 & 10 \\
\hline 9 & 12 & 14 \\
\hline 10 & 13 & 13 \\
\hline 11 & 9 & 14 \\
\hline 12 & 13 & 10 \\
\hline 10 & 13 & 13 \\
\hline 12 & 9 & 12 \\
\hline 13 & 12 & 9 \\
\hline 10 & 10 & 11 \\
\hline 9 & 12 & 10 \\
\hline 10 & 11 & 13 \\
\hline 10 & 11 & 10 \\
\hline 11 & 10 & 14 \\
\hline 12 & 10 & 13 \\
\hline 9 & 9 & 11 \\
\hline 10 & 14 & 11 \\
\hline 13 & 12 & 13 \\
\hline 9 & 14 & 14 \\
\hline 14 & 9 & 12 \\
\hline 13 & 14 & 12 \\
\hline 11 & 13 & 10 \\
\hline 12 & 12 & 11 \\
\hline 10 & 11 & 13 \\
\hline 11 & 10 & 14 \\
\hline 14 & 13 & 13 \\
\hline 12 & 10 & 9 \\
\hline 12 & 9 & 13 \\
\hline
\end{tabular}

\begin{tabular}{|c|c|c|}
\hline 10 & 13 & 11 \\
\hline 11 & 13 & 11 \\
\hline 12 & 13 & 9 \\
\hline 13 & 12 & 13 \\
\hline 11 & 11 & 10 \\
\hline 11 & 11 & 10 \\
\hline 14 & 13 & 11 \\
\hline 9 & 10 & 11 \\
\hline 14 & 13 & 12 \\
\hline 14 & 13 & 12 \\
\hline 13 & 14 & 11 \\
\hline 9 & 12 & 11 \\
\hline 10 & 12 & 12 \\
\hline 11 & 14 & 12 \\
\hline 13 & 11 & 14 \\
\hline 9 & 9 & 13 \\
\hline 13 & 14 & 11 \\
\hline 9 & 12 & 13 \\
\hline 12 & 11 & 9 \\
\hline 11 & 14 & 9 \\
\hline 13 & 10 & 9 \\
\hline 13 & 12 & 9 \\
\hline 14 & 12 & 10 \\
\hline 14 & 11 & 10 \\
\hline 11 & 9 & 9 \\
\hline 13 & 9 & 12 \\
\hline 10 & 11 & 9 \\
\hline 9 & 10 & 9 \\
\hline 13 & 13 & 12 \\
\hline 12 & 11 & 14 \\
\hline 11 & 14 & 14 \\
\hline 14 & 13 & 12 \\
\hline 12 & 12 & 14 \\
\hline 12 & 10 & 12 \\
\hline 14 & 14 & 12 \\
\hline 13 & 10 & 10 \\
\hline 12 & 14 & 11 \\
\hline 10 & 10 & 11 \\
\hline 10 & 11 & 9 \\
\hline 14 & 9 & 14 \\
\hline 9 & 12 & 9 \\
\hline 11 & 10 & 11 \\
\hline 10 & 9 & 13 \\
\hline 14 & 13 & 11 \\
\hline
\end{tabular}




\begin{tabular}{|c|c|c|}
\hline 13 & 11 & 12 \\
\hline 12 & 12 & 13 \\
\hline 11 & 11 & 14 \\
\hline 9 & 12 & 14 \\
\hline 13 & 9 & 10 \\
\hline 9 & 14 & 10 \\
\hline 9 & 13 & 14 \\
\hline 12 & 13 & 12 \\
\hline 9 & 13 & 12 \\
\hline 13 & 11 & 12 \\
\hline 13 & 12 & 13 \\
\hline 13 & 12 & 12 \\
\hline 9 & 12 & 10 \\
\hline 12 & 10 & 11 \\
\hline 12 & 10 & 11 \\
\hline 14 & 11 & 14 \\
\hline 12 & 10 & 12 \\
\hline 13 & 13 & 13 \\
\hline 11 & 14 & 13 \\
\hline 11 & 9 & 11 \\
\hline 13 & 12 & 12 \\
\hline 9 & 9 & 12 \\
\hline 9 & 13 & 9 \\
\hline 10 & 14 & 12 \\
\hline 11 & 9 & 13 \\
\hline 13 & 14 & 11 \\
\hline 13 & 9 & 14 \\
\hline 9 & 13 & 13 \\
\hline 11 & 13 & 11 \\
\hline 12 & 12 & 11 \\
\hline 11 & 14 & 11 \\
\hline 12 & 14 & 13 \\
\hline 12 & 12 & 13 \\
\hline 10 & 9 & 11 \\
\hline 11 & 10 & 13 \\
\hline 9 & 10 & 14 \\
\hline 14 & 9 & 13 \\
\hline 10 & 9 & 13 \\
\hline 9 & 12 & 9 \\
\hline 11 & 14 & 11 \\
\hline 10 & 11 & 12 \\
\hline 11 & 11 & 11 \\
\hline 11 & 14 & 9 \\
\hline 14 & 14 & 10 \\
\hline
\end{tabular}

\begin{tabular}{|c|c|c|}
\hline 14 & 13 & 14 \\
\hline 9 & 14 & 9 \\
\hline 13 & 13 & 14 \\
\hline 10 & 11 & 9 \\
\hline 11 & 12 & 13 \\
\hline 12 & 10 & 12 \\
\hline 14 & 10 & 10 \\
\hline 11 & 13 & 12 \\
\hline 14 & 12 & 9 \\
\hline 10 & 11 & 13 \\
\hline 13 & 12 & 12 \\
\hline 12 & 13 & 9 \\
\hline 12 & 12 & 9 \\
\hline 13 & 12 & 9 \\
\hline 12 & 12 & 9 \\
\hline 10 & 12 & 11 \\
\hline 9 & 9 & 13 \\
\hline 14 & 13 & 12 \\
\hline 10 & 14 & 12 \\
\hline 9 & 11 & 14 \\
\hline 12 & 14 & 9 \\
\hline 14 & 11 & 14 \\
\hline 13 & 14 & 9 \\
\hline 10 & 11 & 12 \\
\hline
\end{tabular}

From the above table-1, the generation of solar power in each of the three buildings on an annual basis is calculated. Moreover, the number of vehicles arriving to the buildings (charging stations) for charging an EV is computed on an annual basis. It is shown in the below table- 2 .

Table-2. Number of vehicles arriving to the buildings

\begin{tabular}{|l|}
\hline \multicolumn{1}{|c|}{\begin{tabular}{c|} 
Number of \\
vehicles
\end{tabular}} \\
\hline 1 \\
\hline 3 \\
\hline 3 \\
\hline 1 \\
\hline 1 \\
\hline 3 \\
\hline 4 \\
\hline 4 \\
\hline 1 \\
\hline
\end{tabular}



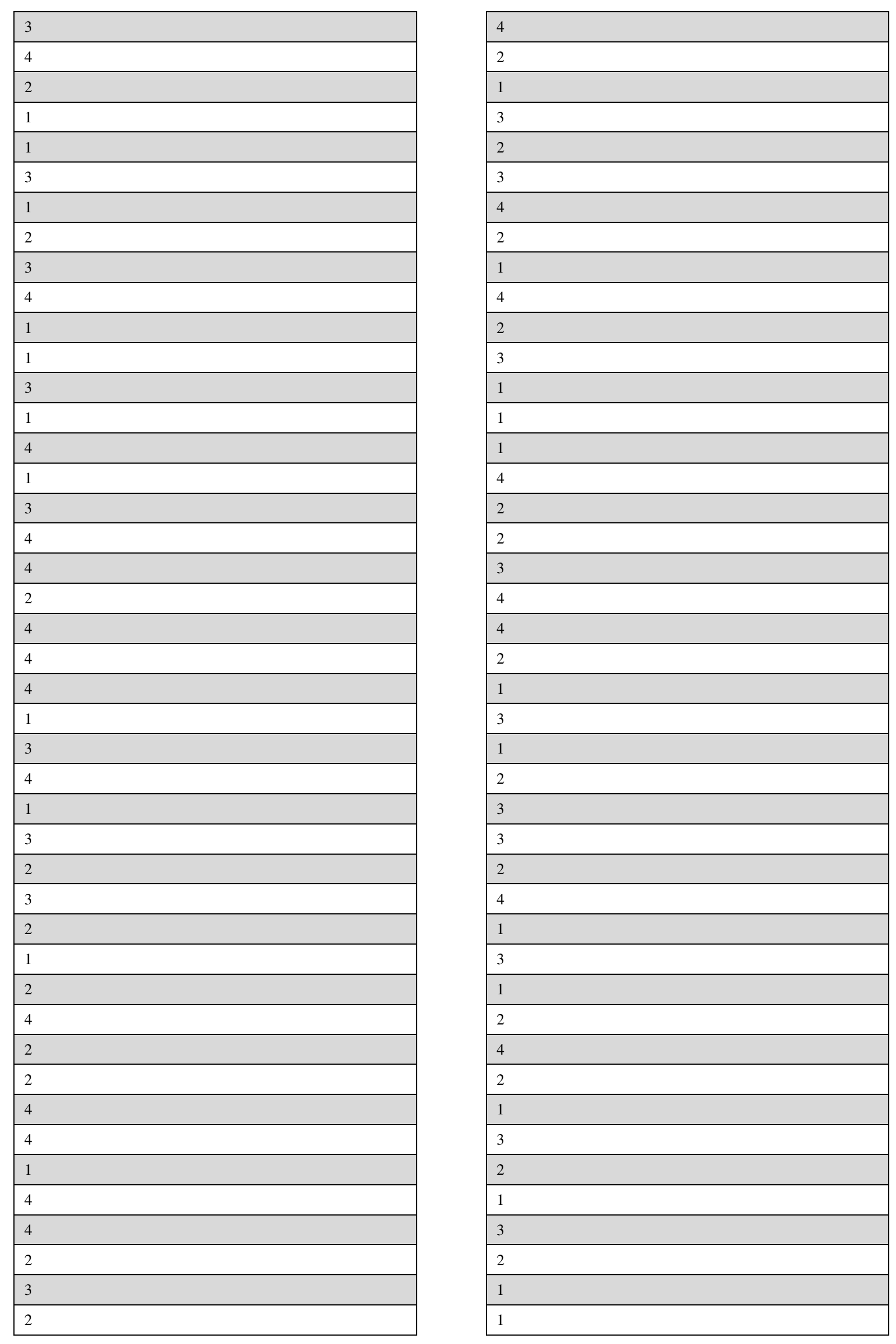

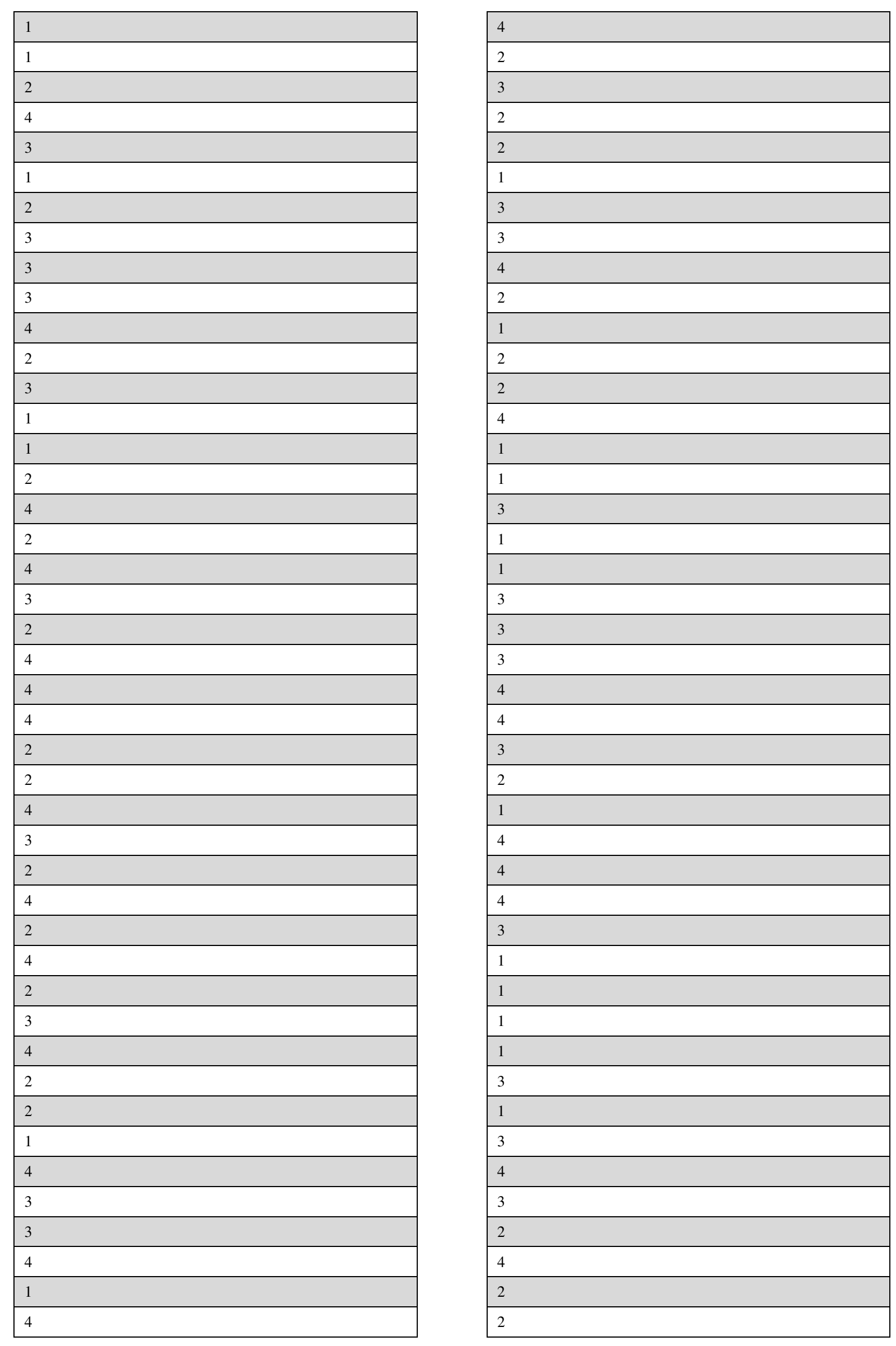

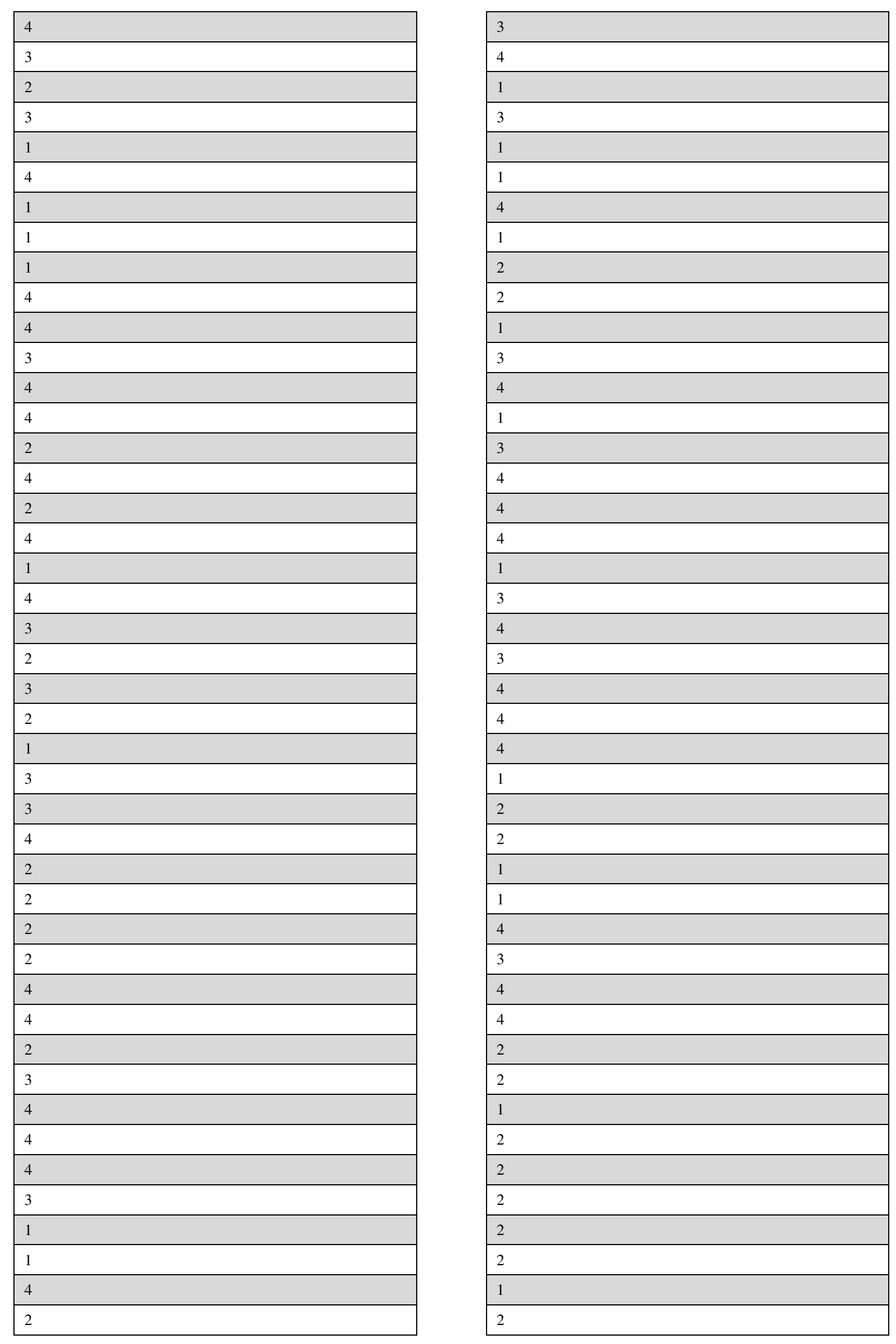

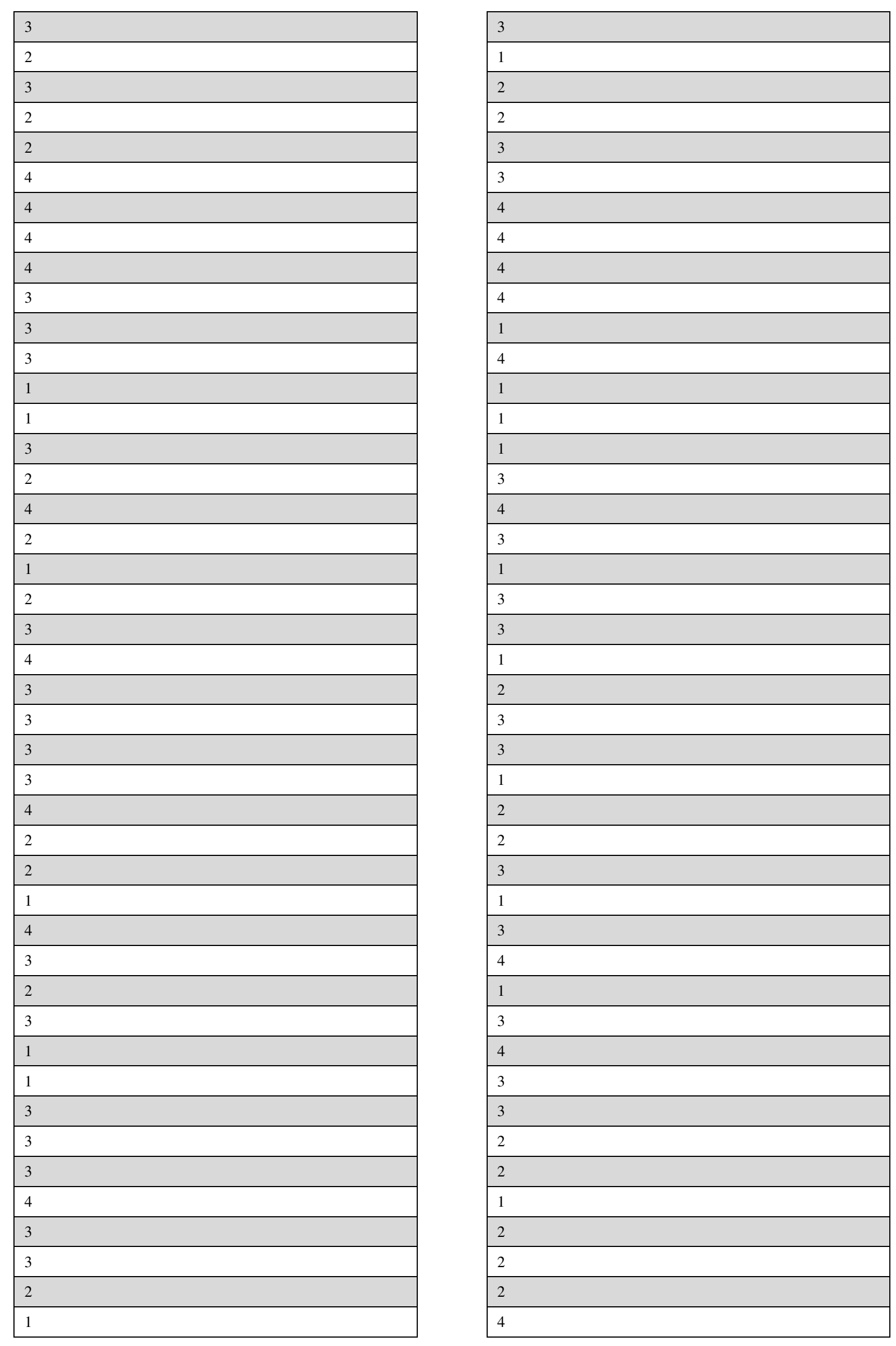


\begin{tabular}{|l|}
\hline 2 \\
\hline 4 \\
\hline 4 \\
\hline 2 \\
\hline
\end{tabular}

From the above table-2, the number of EVs arriving to the buildings to get their vehicles charged are calculated for 365 days. The variation in the number of EVs arrival is found through the above table-2.

In addition, the power generated by solar in each of the buildings is calculated as shown in the below figure.6.

\begin{tabular}{|c|c|c|c|c|}
\hline & W Gen B1 & Solar PW Gen B2 & Solar PW Gen B3 & \\
\hline 1 & 5 & 14 & 33 & ^ \\
\hline 2 & 23 & 24 & 15 & $\equiv$ \\
\hline 3 & 24 & 5 & 15 & \\
\hline 4 & 5 & 14 & 15 & \\
\hline 5 & 5 & 32 & 14 & \\
\hline 6 & 24 & 33 & 32 & \\
\hline 7 & 33 & 23 & 5 & \\
\hline 8 & 32 & 15 & 24 & \\
\hline 9 & 5 & 6 & 14 & \\
\hline 10 & 23 & 15 & 14 & \\
\hline 11 & 33 & 23 & 23 & \\
\hline 12 & 14 & 15 & 33 & \\
\hline 13 & 5 & 15 & 24 & \\
\hline 14 & 6 & 6 & 5 & \\
\hline+15 & 3 & 20 & 3? & \\
\hline
\end{tabular}

Figure.6. Solar power generation

From the above figure.6, it is found that the power generation of solar energy varies for each buildings based on its availability and the number of vehicles arriving to the buildings to get the EVs charged. Additionally, the power stored in battery is also computed as shown in the below figure. 7 .

\begin{tabular}{|c|c|c|c|c|}
\hline & W) & Bat PW gen $B 2(K W)$ & Bat $P W$ gen $B 3(K W)$ & \\
\hline 1 & -3 & 22 & 74 & $4 \propto$ \\
\hline 2 & 32 & 36 & 10 & $\equiv$ \\
\hline 3 & 35 & -19 & 10 & \\
\hline 4 & -3 & 23 & 25 & \\
\hline 5 & -2 & 73 & 22 & \\
\hline 6 & 35 & 59 & 57 & \\
\hline 7 & 52 & 25 & -26 & \\
\hline 8 & 51 & 2 & 28 & \\
\hline 9 & -3 & 1 & 22 & \\
\hline 10 & 32 & 10 & 7 & 7 \\
\hline 11 & 52 & 23 & 24 & \\
\hline 12 & 14 & 19 & 69 & \\
\hline 13 & -3 & 25 & 50 & 0 \\
\hline 14 & -1 & 0 & -3 & 3 \\
\hline 15 & 139 & in & 1 & 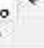 \\
\hline
\end{tabular}

Figure.7. Power stored in battery
From the above figure.7, the total power stored in a battery in each buildings for charging an EV is computed. This also varies in each buildings based on its availability.

The Net Present Cost and COE of solar, biomass and battery in each of the three buildings is given in the below figure. 8 .

\begin{tabular}{|c|c|c|c|c|c|c|c|c|c|c|c|}
\hline \multicolumn{4}{|c|}{ 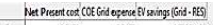 } & \multicolumn{4}{|c|}{ We hivent catct cot } & \multirow{2}{*}{\multicolumn{4}{|c|}{ epponse Elssaingy (Gond-RES) }} \\
\hline & 6850 & 0980 & trower & & 2153 & 2151 & 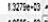 & & & & \\
\hline & & & 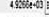 & 2 & & & & & 23217 & $2: 217$ & \\
\hline 3 & 1612 & 1618 & $(4 \mathrm{~s} \times \mathrm{x}, \mathrm{e})$ & 3 & 08900 & OKM & $\operatorname{sen} \theta e^{2}$ & 3 & 20304 & $2: 604$ & 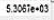 \\
\hline 5 & 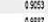 & 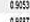 & tantest & 1 & 年 & 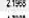 & $1020=3$ & 4 & & & $1887 t e-03$ \\
\hline & & & & & (2) & & & 3 & 4006 & & \\
\hline 7 & t=13 & tats & tertarest & 7 & $1=0$ & 200 & $68 x+5$ & 7 & 0.047 & 0.479 & 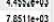 \\
\hline 8 & & & & & 22817 & in & 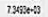 & 8 & 36122 & & 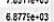 \\
\hline & 1053 & 0.050 & instent & 9 & 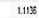 & 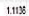 & walles: & 9 & 21551 & 21551 & 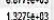 \\
\hline 10 & 1269 & 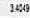 & $48 \mathrm{~s}=01$ & 10 & $2.28 \pi$ & 22817 & smates & 10 & 2.1551 & 21551 & 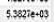 \\
\hline & 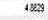 & (1) & Eateres & II & 32699 & 30489 & 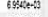 & II & 3.465 & 3.465 & 69938ce-03 \\
\hline$\frac{12}{12}$ & 步 & (2) & 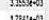 & 13 & 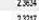 & 年 & 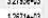 & 12 & 4 & 4628 & $23870-03$ \\
\hline & $=0$ & 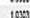 & 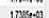 & II & 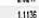 & $\ldots$ & 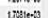 & ${ }^{13}$ & 急 & 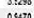 & 2860154 \\
\hline 15 & jues & 3 & [silthel] & & $i \pi x$ & $4 \pi \%$ & 456403 & & 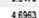 & 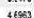 & 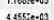 \\
\hline & 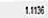 & uns & 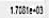 & 15 & 3012 & 3012 & 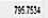 & 16 & 39115 & 39715 & 8010589 \\
\hline 17 & $23 \mathrm{am}$ & $223 \mathrm{mI}$ & 13:5xos & 17 & 0 & oxes & $30 \mathrm{ntens}$ & p & 2017 & $2: 217$ & $32040+23$ \\
\hline $18 \mathrm{C}$ & 12009 & 360 & 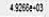 & & 39115 & 3915 & 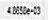 & 18 & 21988 & 21008 & $5.877 t=03$ \\
\hline & (1) & 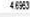 & 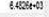 & 19 & 3612 & 3112 & 68776 & 19 & 1.0383 & 1,603 & $78000 \mathrm{i}-03$ \\
\hline 20 & 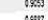 & 然 & sinets & & & 1023 & $127 x=3$ & $x$ & 22384 & 2334 & $1287:-03$ \\
\hline 22 & 3612 & 362 & 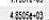 & 23 & $2 \times x$ & $230 x$ & 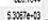 & 4 & 23871 & 2,2717 & $1828 \mathrm{te}=0.33$ \\
\hline & & & & & & & & & & & 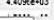 \\
\hline
\end{tabular}

Figure.8. Computation of Net Present Cost, COE and EV savings

From the above figure. 8 , it is found that the net present cost, $\mathrm{COE}$ and EV savings are computed so as to find the efficiency of various source of energy (solar, biomass or battery) for charging an EV.

\subsection{Performance Analysis}

The performance of the solar panel, biomass and battery is charging an EV is individually assessed. It is briefly discussed below.

\subsubsection{Analysis of SPV in charging an EV}

Various SPV parameters are computed for the buildings B1, B2 and B3. It is shown in the below table-3.

Table-3. Computation of various SPV parameters for each buildings

\begin{tabular}{|l|c|c|c|}
\hline & $\begin{array}{l}\text { Building } \\
\text { B1 }\end{array}$ & $\begin{array}{l}\text { Buildin } \\
\text { g B2 }\end{array}$ & $\begin{array}{l}\text { Buildin } \\
\text { g B3 }\end{array}$ \\
\hline $\begin{array}{l}\text { Area of } \\
\text { SPV } \\
\text { panel }\left(m^{2}\right)\end{array}$ & 5.4 & 5.4 & 5.4 \\
\hline $\begin{array}{l}\text { Solar } \\
\text { radiation( } \\
\left.\text { W/ } m^{2}\right)\end{array}$ & 675 & 828 & 782 \\
\hline $\begin{array}{l}\text { Efficiency } \\
\text { of the SPV } \\
\text { panel }(\%)\end{array}$ & 15 & 18 & 16 \\
\hline $\begin{array}{l}\text { Area of } \\
\text { Roof }\left(m^{2}\right)\end{array}$ & 92 & 92 & 92 \\
\hline
\end{tabular}




\begin{tabular}{|l|c|c|c|}
\hline $\begin{array}{l}\text { Area of one } \\
\text { solar } \\
\text { panel }\left(m^{2}\right)\end{array}$ & 23 & 32 & 28 \\
\hline Size $\left(m^{2}\right)$ & 20.4 & 23.4 & 21.4 \\
\hline $\begin{array}{l}\text { Number of } \\
\text { solar panel }\end{array}$ & 4 & 3 & 3 \\
\hline
\end{tabular}

From the above table-3, the below computations are determined. The area of SPV panel, solar radiation and the efficiency of the SPV panel, area of the roof, area of one solar panel, size and the number of solar panel is computed for each of the three buildings B1, $\mathrm{B} 2$ and $\mathrm{B} 3$.

The number of solar panels are calculated for each of the three buildings based on the below formula.

Number of solar panel B1 $=4$

Number of solar panel B2 =

Area_of_Roof_B2/Area_of_one_solar_panel_B2

Number of solar panel B3 =

Area_of_Roof_B3/Area_of_one_solar_panel_B3

From the above computations, power output is determined in each of the buildings as per the below table-4.

Table-4. Computation of power output

\begin{tabular}{|l|c|c|c|}
\hline & $\begin{array}{l}\text { BUILDI } \\
\text { NG B1 }\end{array}$ & $\begin{array}{l}\text { BUILDI } \\
\text { NG B2 }\end{array}$ & $\begin{array}{l}\text { BUILDI } \\
\text { NG B3 }\end{array}$ \\
\hline $\begin{array}{l}\text { Area of SPV } \\
\text { panel }\left(m^{2}\right)\end{array}$ & 5.4 & 5.4 & 5.4 \\
\hline $\begin{array}{l}\text { Solar } \\
\text { radiation(W } \\
\left./ m^{2}\right)\end{array}$ & 675 & 828 & 782 \\
\hline $\begin{array}{l}\text { Efficiency } \\
\text { of the SPV } \\
\text { panel }\left(m^{2}\right)\end{array}$ & 15 & 15 & 15 \\
\hline $\begin{array}{l}\text { Power } \\
\text { output(W) }\end{array}$ & 54675 & 67068 & 63342 \\
\hline
\end{tabular}

From the above computations, the power output for each of the buildings is determined by considering the area of the SPV panel, solar radiation and efficiency of the SPV panel.

Power output B1 $=54675$

Power output B2 $=67068$

Power output B3 = 63342

Hence, it is found that the building B2 shows maximum power output at a rate of 67068 .

\subsubsection{Analysis of Biomass in charging an EV}

The biomass is analyzed in terms of various parameters in charging an EV. It is shown in the below table-5.
Table-5. Analysis of Biomass in accordance with various parameters

\begin{tabular}{|l|c|c|c|}
\hline & BUILDI & BUILDI & BUILDI \\
NG B2 & NG B3 \\
\hline $\begin{array}{l}\text { Overall } \\
\text { energy } \\
\text { conversion } \\
\text { efficiency } \\
\text { (\%) }\end{array}$ & 68 & 70 & 72 \\
\hline $\begin{array}{l}\text { Calorific } \\
\text { value of Bio } \\
\text { mass(KJ/Kg } \\
\text { ) }\end{array}$ & 18 & 18 & 18 \\
\hline $\begin{array}{l}\text { Operating } \\
\text { hours per } \\
\text { day (hrs.) }\end{array}$ & 24 & 24 & 24 \\
\hline $\begin{array}{l}\text { Total fuel } \\
\text { wood(kg) }\end{array}$ & 1 & 1 & 1 \\
\hline $\begin{array}{l}\text { Biomass } \\
\text { generated(K } \\
\text { Wh) }\end{array}$ & 0.1624 & 0.1672 & 0.1720 \\
\hline $\begin{array}{l}\text { Biogas } \\
\text { generated } \\
\text { (Kwh) }\end{array}$ & 1.1860 & 0.610 & 0.941 \\
\hline $\begin{array}{l}\text { State of } \\
\text { charging } \\
\text { (KW) }\end{array}$ & 602 & 1334 & 1400 \\
\hline
\end{tabular}

From the above table-5, the overall energy conversion efficiency, calorific value of biomass, operating hours per days, total fuel woods, biomass generated and state of charging is determined for each buildings. Here, it is found that B3 is high in terms of the above mentioned metrics in comparison to other buildings.

In addition, the average biogas fuel price, fuel wastage and fuel cost is calculated in each buildings as shown in the below table- 6 .

Table-6. Analysis of using biomass for EV charging in terms of costs

\begin{tabular}{|c|c|c|c|}
\hline & $\begin{array}{l}\text { BUILDI } \\
\text { NG B1 }\end{array}$ & $\begin{array}{l}\text { BUILDIN } \\
\text { G B2 }\end{array}$ & $\begin{array}{l}\text { BUILDIN } \\
\text { G B3 }\end{array}$ \\
\hline $\begin{array}{l}\text { Average } \\
\text { biomass } \\
\text { fuel price } \\
\text { (rs) }\end{array}$ & 204.4 & 204.4 & 204.4 \\
\hline $\begin{array}{l}\text { Fuel } \\
\text { wastage } \\
(\%)\end{array}$ & 30 & 20 & 35 \\
\hline 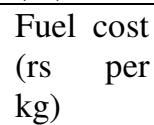 & 6132 & 4088 & 7154 \\
\hline
\end{tabular}


From the above table- 6 , computation of average biogas fuel price, fuel wastage and fuel costs is computed. It is found that the building B3 has high fuel cost, fuel wastage and average biogas fuel price in comparison to the other two buildings. Additionally, various parameters are analyzed for EV charging using biomass as shown in the below table-7.

Table-7. Analysis of parameters for charging an EV using biomass

\begin{tabular}{|l|c|c|c|}
\hline & $\begin{array}{l}\text { BUILDI } \\
\text { NG B1 }\end{array}$ & $\begin{array}{l}\text { BUILDI } \\
\text { NG B2 }\end{array}$ & $\begin{array}{l}\text { BUILDI } \\
\text { NG B3 }\end{array}$ \\
\hline $\begin{array}{l}\text { Capital } \\
\text { cost (rs) }\end{array}$ & 43072.19 & 43072.19 & 43072.19 \\
\hline $\begin{array}{l}\text { Operation } \\
\text { and } \\
\text { maintenan } \\
\text { ce cost (rs) }\end{array}$ & 1973.14 & 1973.14 & 1973.14 \\
\hline $\begin{array}{l}\text { Replacem } \\
\text { ent cost } \\
\text { (rs) }\end{array}$ & 22000 & 28000 & 30000 \\
\hline $\begin{array}{l}\text { Fuel cost } \\
\text { (rs) }\end{array}$ & 75 & 75 & 75 \\
\hline $\begin{array}{l}\text { Life spean } \\
\text { span(years }\end{array}$ & 5 & 5 & 20 \\
\hline $\begin{array}{l}\text { Life span } \\
\text { of } \\
\text { battery(ye } \\
\text { ars) }\end{array}$ & 57120.14 & 73120.33 & 75120.33 \\
\hline $\begin{array}{l}\text { Number of } \\
\text { times } \\
\text { needs to } \\
\text { replace } \\
\text { (per year) }\end{array}$ & 3 & 3 & 3 \\
\hline $\begin{array}{l}\text { Net } \\
\text { present } \\
\text { cost (rs) }\end{array}$ & & & \\
\hline
\end{tabular}

From the above table-7, capital cost, Operation and maintenance cost, Replacement cost, Fuel cost, Life span (years), Life span of battery (years), Number of times needs to replace (per year) and Net present cost is computed for each buildings. It is found that B3 is higher in terms of all the above mentioned metrics than B1 and B2.

The analysis of various costs for charging an EV using biomass is give in the below table- 8 .

Table-8. Analysis of costs for charging an EV using biomass

\begin{tabular}{|l|l|l|l|}
\hline & BUILDI & BUILDI & BUILDI \\
NG B1 & NG B2 & NG B3 \\
\hline
\end{tabular}

\begin{tabular}{|l|l|l|l|}
\hline $\begin{array}{l}\text { Capital } \\
\text { cost (rs) }\end{array}$ & 13703.56 & 13703.56 & 13703.56 \\
\hline $\begin{array}{l}\text { Operation } \\
\text { cost (rs) }\end{array}$ & 548.23 & 274 & 274 \\
\hline $\begin{array}{l}\text { Maintena } \\
\text { nce cost } \\
\text { (rs) }\end{array}$ & 274.23 & 528 & 568 \\
\hline $\begin{array}{l}\text { Replacem } \\
\text { ent cost } \\
\text { (rs) }\end{array}$ & 18000 & 18000 & 18000 \\
\hline $\begin{array}{l}\text { Total net } \\
\text { present } \\
\text { cost (rs) }\end{array}$ & 32526.02 & 32505.56 & 32545.56 \\
\hline
\end{tabular}

From the above table.8, the capital cost, operation cost, maintenance cost, replacement cost and total net present cost is computed for charging an EV from the three buildings.

The annual energy generation is computed as shown in the below table.9.

Table-9. Annual energy generation from the three buildings

\begin{tabular}{|l|l|l|l|}
\hline & $\begin{array}{l}\text { BUILDIN } \\
\text { G B1 }\end{array}$ & $\begin{array}{l}\text { BUILDIN } \\
\text { G B2 }\end{array}$ & $\begin{array}{l}\text { BUILDIN } \\
\text { G B3 }\end{array}$ \\
\hline $\begin{array}{l}\text { Total } \\
\text { net } \\
\text { present } \\
\text { cost(rs) }\end{array}$ & 800 & 900 & 850 \\
\hline $\begin{array}{l}\text { Capacit } \\
\text { y } \\
\text { recover } \\
\text { y factor } \\
\text { (\%) }\end{array}$ & 60 & 60 & 60 \\
\hline $\begin{array}{l}\text { Total } \\
\text { annual } \\
\text { energy } \\
\text { generat } \\
\text { ed } \\
\text { (KWH) }\end{array}$ & 90 & 92 & 93 \\
\hline $\begin{array}{l}\text { Cost of } \\
\text { energy } \\
\text { (Rs) }\end{array}$ & 5.3333 & 5.8695 & 5.4838 \\
\hline
\end{tabular}

From the above table.9, the total net present cost, capacity recovery factor, total annual energy generated and COE is computed.

\subsubsection{Analysis of Battery in charging an EV}

The battery is used in charging an EV only when solar energy or biomass is insufficient. The overall net present cost of the three sources for EV charging is shown in the below table- 10 .

Table-10. Computation of Net Present Cost 


\begin{tabular}{|l|l|l|l|}
\hline & $\begin{array}{l}\text { BUILDI } \\
\text { NG B1 }\end{array}$ & $\begin{array}{l}\text { BUILDI } \\
\text { NG B2 }\end{array}$ & $\begin{array}{l}\text { BUILDI } \\
\text { NG B3 }\end{array}$ \\
\hline $\begin{array}{l}\text { Capital } \\
\text { cost of the } \\
\text { solar } \\
\text { panel(rs) }\end{array}$ & 65775.92 & 65775.92 & 65775.92 \\
\hline $\begin{array}{l}\text { No of } \\
\text { solar } \\
\text { panel }\end{array}$ & 4 & 3 & 3 \\
\hline $\begin{array}{l}\text { Capital } \\
\text { cost of the } \\
\text { battery(rs } \\
\text { ) }\end{array}$ & 13703.56 & 65775.92 & 65775.92 \\
\hline $\begin{array}{l}\text { No of } \\
\text { battery }\end{array}$ & 4 & 3 & 4 \\
\hline $\begin{array}{l}\text { Capital } \\
\text { cost of the } \\
\text { inverter(r } \\
\text { s) }\end{array}$ & 12410 & 12410 & 12410 \\
\hline $\begin{array}{l}\text { No of } \\
\text { inverter }\end{array}$ & 4 & 4 & 4 \\
\hline $\begin{array}{l}\text { Capital } \\
\text { cost of the } \\
\text { generator } \\
\text { (rs) }\end{array}$ & 645000 & 645000 & 645000 \\
\hline $\begin{array}{l}\text { No of } \\
\text { generator }\end{array}$ & 3 & 3 & 3 \\
\hline $\begin{array}{l}\text { Net } \\
\text { present } \\
\text { cost(rs) }\end{array}$ & $26,42,050$ & $\begin{array}{l}24,20,406 \\
.20\end{array}$ & $\begin{array}{l}22,36,779 \\
.24\end{array}$ \\
\hline
\end{tabular}

From the above table-10, the capital cost of solar panel, battery and inverter is determined. The number of solar panel, battery and inverter is found. Finally, the net present cost is determined. Here, the net present cost of $\mathrm{B} 1$ is found to be higher than the other two.

In addition, the depth of discharge, capacity of battery and minimum capacity for the three buildings is computed as per the below table-11.

Table-11. Analysis of various parameters in charging an EV through battery

\begin{tabular}{|l|c|c|c|}
\hline & $\begin{array}{l}\text { BUILDIN } \\
\text { G B1 }\end{array}$ & $\begin{array}{l}\text { BUILDIN } \\
\text { G B2 }\end{array}$ & $\begin{array}{l}\text { BUILDIN } \\
\text { G B3 }\end{array}$ \\
\hline $\begin{array}{l}\text { Depth of } \\
\text { Dischar } \\
\text { ge (\%) }\end{array}$ & 40 & 60 & 60 \\
\hline $\begin{array}{l}\text { Capacit } \\
\text { y of } \\
\text { Battery } \\
(\%)\end{array}$ & 90 & 95 & 90 \\
\hline $\begin{array}{l}\text { Minimu } \\
\text { m } \\
\begin{array}{l}\text { Capacit } \\
\text { y \%) }\end{array}\end{array}$ & 36 & 57 & 54 \\
\hline
\end{tabular}

From the above table-11, it is found that the building B2 shows high depth of discharge, capacity of battery and minimum capacity when compared to the other two buildings.

Additionally, the net present operation and maintenance cost is determined as shown in the below table-12.

Table-12. Net Present Operation and Maintenance Cost

\begin{tabular}{|l|l|l|l|}
\hline & $\begin{array}{l}\text { BUILDI } \\
\text { NG B1 }\end{array}$ & $\begin{array}{l}\text { BUILDI } \\
\text { NG B2 }\end{array}$ & $\begin{array}{l}\text { BUILDI } \\
\text { NG B3 }\end{array}$ \\
\hline $\begin{array}{l}\text { Initial } \\
\text { maintenan } \\
\text { ce cost of } \\
\text { SPV (rs) }\end{array}$ & 861.7 & 1200 & 1120 \\
\hline $\begin{array}{l}\text { No of } \\
\text { SPV }\end{array}$ & 4 & 4 & 4 \\
\hline $\begin{array}{l}\text { Initial } \\
\text { maintenan } \\
\text { ce cost of } \\
\text { battery(rs) }\end{array}$ & 548.23 & 568 & 520 \\
\hline $\begin{array}{l}\text { No of } \\
\text { battery }\end{array}$ & 3 & 3 & 3 \\
\hline $\begin{array}{l}\text { Initial } \\
\text { maintenan } \\
\text { ce cost of } \\
\text { inverter(rs } \\
\text { ) }\end{array}$ & 300 & 400 & 420 \\
\hline $\begin{array}{l}\text { NO of } \\
\text { inverter }\end{array}$ & 4 & 4 & 4 \\
\hline $\begin{array}{l}\text { Initial } \\
\text { maintenan } \\
\text { ce cost of } \\
\text { generator( } \\
\text { rs) }\end{array}$ & 2100 & 2100 & 2700 \\
\hline $\begin{array}{l}\text { No of } \\
\text { generator }\end{array}$ & 4 & 4 & 4 \\
\hline $\begin{array}{l}\text { Net } \\
\text { present } \\
\text { operation } \\
\text { and } \\
\text { maintenan } \\
\text { ce cost(rs) }\end{array}$ & 14691.49 & 17704 & 18520 \\
\hline
\end{tabular}

From the above table-12, the computation of Initial maintenance cost of SPV, battery, inverter and generator is determined. On the other hand, the number of SPV, battery, inverter and generator is found. Finally, the net present operation and maintenance cost is determined. 


\subsection{Comparative analysis}

The proposed novel OFA is compared with the existing systems to find the efficiency of the proposed system than the existing methods.

Table-13. Analysis of the proposed and existing methods [31]

\begin{tabular}{|c|c|c|c|c|}
\hline & $\begin{array}{l}\text { Proposed } \\
\text { method }\end{array}$ & SA & GA & $\begin{array}{l}\text { MO } \\
\text { PSO }\end{array}$ \\
\hline $\begin{array}{l}\text { The number of } \\
\text { PV panels }\end{array}$ & 11.1 & $\begin{array}{l}11 . \\
76\end{array}$ & $\begin{array}{l}11 . \\
43\end{array}$ & $\begin{array}{l}11.2 \\
3\end{array}$ \\
\hline $\begin{array}{l}\text { The number of } \\
\text { batteries }\end{array}$ & 35 & 17 & 25 & 30 \\
\hline $\begin{array}{l}\text { COE (Cost Of } \\
\text { Energy) }\end{array}$ & 0.315 & $\begin{array}{l}0.2 \\
86\end{array}$ & $\begin{array}{l}0.2 \\
97\end{array}$ & $\begin{array}{l}0.30 \\
6\end{array}$ \\
\hline $\begin{array}{l}\text { Computing } \\
\text { time }\end{array}$ & 10.25 & $\begin{array}{l}267 \\
.44\end{array}$ & $\begin{array}{l}325 \\
.63\end{array}$ & $\begin{array}{l}13.0 \\
4\end{array}$ \\
\hline
\end{tabular}

From the above table-13, the number of PV panels, the number of batteries, COE and computing time is determined for the proposed and existing methods. From the results, it is found that the proposed method used only minimum number of PV panels with high count of batteries and shows high COE thereby exhibiting minimum computing time to charge an EV. It is graphically shown in the below figure.9.

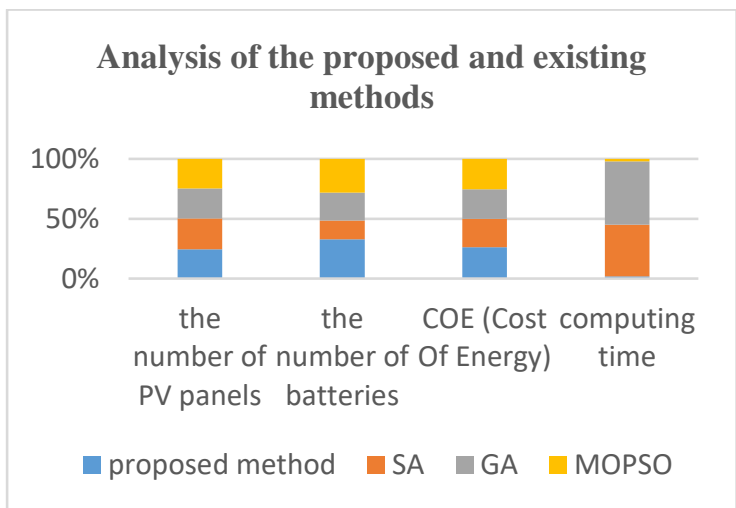

Figure.9. Comparative analysis of the proposed and existing methods [31]

From the figure.9, it is clear that the proposed system is effective than the existing system in accordance with the above mentioned parameters. In addition, the efficiency of the proposed PV system is evaluated by comparing it with the existing system. It is shown in the below figure.10.
Evaluating the efficiency of the proposed system

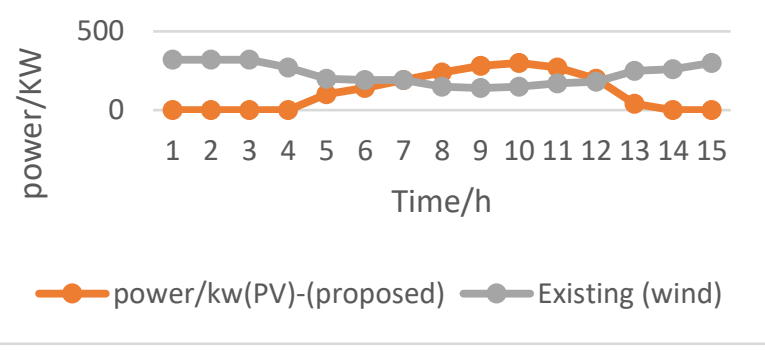

Figure.10. Comparative analysis of the proposed

(PV) and existing method (wind) [31]

From the above figure.10, it is clear that the proposed system using PV panel generates high power with minimum time when compared to the existing system using wind as an energy source for charging an EV.

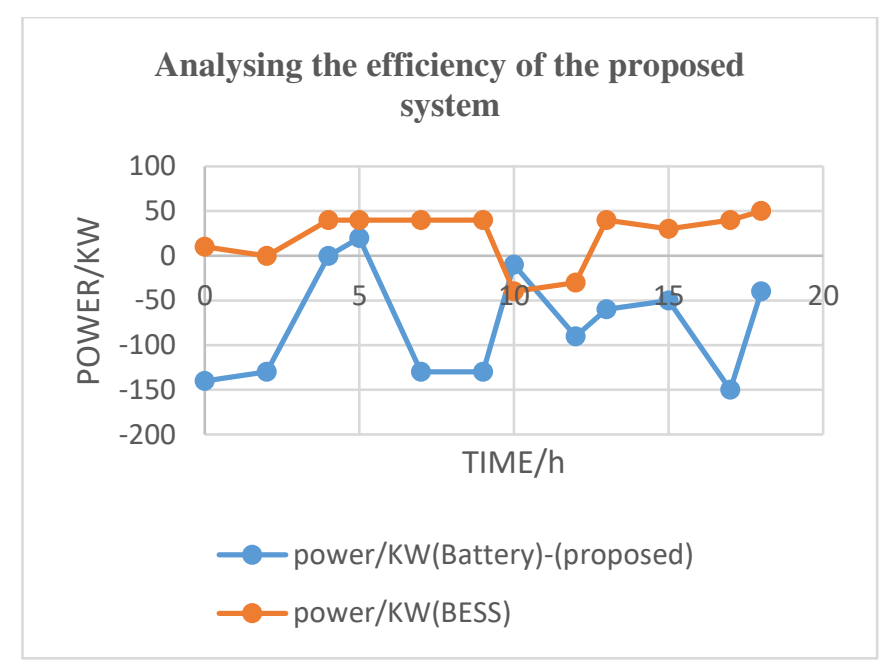

Figure.11. Comparative analysis of the proposed (Battery) and existing method (BESS) [31]

From the above figure.11, it is clear that the proposed methodology is effective than the existing method for charging an EV with high power in limited time.

In addition, the COE (Cost of Energy) is assessed for the existing system and it is shown in the below figure. 12 . 


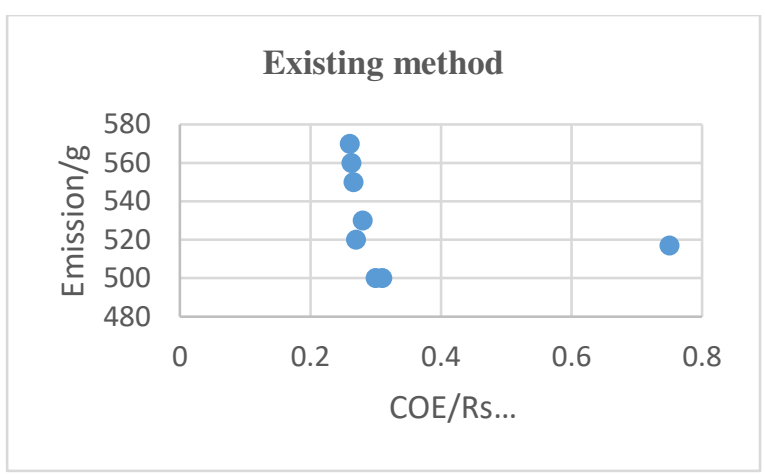

Figure.12. Evaluating the COE for the existing system [31]

Additionally, COE is computed for the proposed system which is shown in the below figure.13.

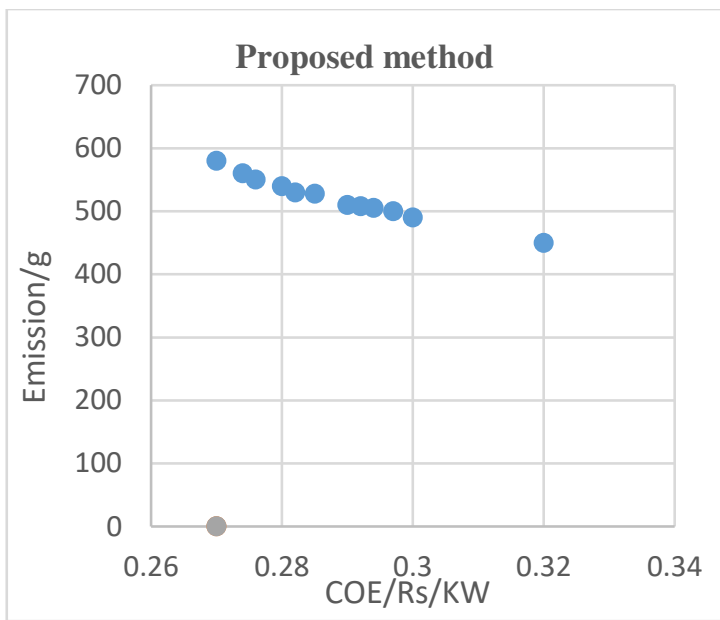

Figure.13. Evaluating the COE for the proposed system

From the above figure.13, it is found that the COE is high for the proposed system in comparison to the existing system as shown in figure. 12 .

Thus, the proposed novel optimal firefly algorithm (OFA) efficiently finds the suitable source of energy for charging an $\mathrm{EV}$ with high efficiency in terms of cost and energy than the existing methods. The proposed method revealed that solar energy is effective in charging an electric vehicle than biomass or battery.

\section{CONCLUSION}

The study introduced a novel Optimal Firefly Algorithm to find the efficient renewable energy sources (solar, biomass or battery) for charging an Electric Vehicle (EV). It calculated the number of vehicles arriving to the charging stations. It also computed the cost of solar energy, biomass and battery for charging an EV. This computation is regularly done for a year. Thus an annual computation is performed. The proposed novel Optimal Firefly algorithm is used to find the efficient energy source by performing the implementation through Simulink. The results exhibited that the use of solar energy as an energy source for charging an EV costs less when compared to biomass and battery. The efficiency of the proposed system is analyzed by comparing it with the existing methodologies. The comparative analysis reveals that the proposed system is effective than the existing methods in finding the efficient energy source (solar energy, biomass or battery) for EV charging.

Declaration of interest

I Am Nishant Kumar Hereby State That The Manuscript Title Entitled "Identification of Efficient Energy Source among Solar, Biomass and Battery for Electric Vehicle Charging using Novel Optimal Firefly Algorithm" Submitted To The Wireless Personal Applications, I Confirm That This Work Is Original And Has Not Been Published Elsewhere, Nor Is It Currently Under Consideration For Publication Elsewhere. And I Am Research Scholar In the Department of Electrical Engineering, National Institute of Technology, and Jamshedpur, India.

I'm the corresponding author of our paper, my contribution work on this paper is to Writing, developing, and reviewing the content of the manuscript. And my co-author Kumari Namrata works were to cite the figure, table and references. Equally I have done $50 \%$ and my Co-author have done $50 \%$. We are the entire contributors of our paper. And no other third party people were involved in this paper.

\section{DECLARATIONS}

\section{- Conflict Of Interest}

I confirm that this work is original and has either not been published elsewhere, or is currently under consideration for publication elsewhere. None of the authors have any competing interests in the manuscript.

\section{- $\quad$ Funding}

This research work was not funded by any organization/institute/agency.

\section{- Author Contribution Statement}

I Am Nishant Kumar Hereby State That The Manuscript Title Entitled "Identification of Efficient Energy Source among Solar, Biomass and Battery for Electric Vehicle Charging using Novel Optimal Firefly Algorithm" Submitted To The Wireless Personal Communications, I Confirm That This Work Is Original And Has Not 
Been Published Elsewhere, Nor Is It Currently Under Consideration For Publication Elsewhere. And I Am Research Scholar In the Department of Electrical Engineering, National Institute of Technology, and Jamshedpur, India.

I'm the corresponding author of our paper, my contribution work on this paper is to Writing, developing, and reviewing the content of the manuscript. And my co-author Kumari Namrata works were to cite the figure, table and references. Equally I have done $50 \%$ and my Co-author have done $50 \%$. We are the entire contributors of our paper. And no other third party people were involved in this paper.

- Data Availability

1. https://doi.org/10.1016/i.ijepes.2018.0 8.001

2. https://doi.org/10.1080/23080477.2018 .1437323

3. https://www.proquest.com/openview/977c 80703c3e7573fe088dc110246bf2/1?pqorigsite $=$ gscholar $\& \mathrm{cbl}=18750 \&$ diss $=\mathrm{y}$

4. https://doi.org/10.1016/i.energy.2018.0 7.068

5. https://doi.org/10.1016/i.apenergy.202 0.115562

6. https://doi.org/10.1109/pesgm.2017.82 74685

7. https://doi.org/10.1016/j.ijhydene.2020 .02 .018

8. https://doi.org/10.1016/j.enconman.20 20.113161

9. https://doi.org/10.1109/ptc.2019.8810 736

10. https://scholar.google.com/scholar?hl=en \&as_sdt=0\%2C5\&q=F.+AHMAD $\% 2 \mathrm{C}+$ $\% 22 \mathrm{ANALYSIS}+\mathrm{OF}+\mathrm{MICROGRIDS}+\mathrm{F}$ OR+PLUG-

IN+HYBRID+ELECTRIC+VEHICLES+ CHARGING+STATIONS\%2C\%22+ALI GARH+MUSLIM+UNIVERSITY+ALIG ARH\%2C+2019\&btnG=

11. https://doi.org/10.1016/i.scs.2017.05.0 07

12. https://doi.org/10.1016/i.jclepro.2019.1 19100

13. https://doi.org/10.1016/i.energy.2018.1 2.083

14. https://doi.org/10.1016/j.jclepro.2018.0 5.103

15. $\underline{\text { https://doi.org/10.1016/j.enconman.20 }}$ 19.01.107

16. https://doi.org/10.3390/en12010074

17. https://doi.org/10.1016/i.rser.2018.02.0 34

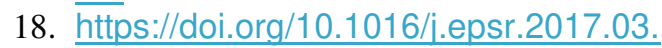
009

19. $\overline{\text { https://doi.org/10.1016/j.renene.2018.0 }}$ 2.126
20. https://doi.org/10.3390/coatings 80702 $\underline{51}$

21. $\underline{\text { https://doi.org/10.1016/j.jclepro.2019.0 }}$ 5.023

22. https://jser.ut.ac.ir/article 68813.html

23. https://doi.org/10.3390/en10101536

24. https://doi.org/10.2514/6.2020-3663

25. https://doi.org/10.1016/j.jclepro.2020.1 23593

26. https://doi.org/10.1002/er.4373

27. https://doi.org/10.1016/i.jclepro.2020.1 24863

28. https://doi.org/10.1016/i.rser.2019.109 $\underline{618}$

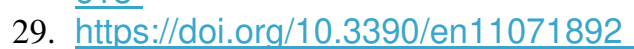

30. https://doi.org/10.1002/20507038.12668

31. https://doi.org/10.1016/i.jclepro.2020.1 25564

\section{REFERENCES}

[1] J. Domínguez-Navarro, R. Dufo-López, J. Yusta-Loyo, J. Artal-Sevil, and J. Bernal-Agustín, "Design of an electric vehicle fast-charging station with integration of renewable energy and storage systems," International Journal of Electrical Power \& Energy Systems, vol. 105, pp. 46-58, 2019.

[2] W. Khan, A. Ahmad, F. Ahmad, and M. Saad Alam, "A comprehensive review of fast charging infrastructure for electric vehicles," Smart Science, vol. 6, pp. 256-270, 2018.

[3] D. Alame, "Assessing and Mitigating Impacts of Electric Vehicles on Active Distribution Systems," 2019.

[4] S. Bellocchi, M. Gambini, M. Manno, T. Stilo, and M. Vellini, "Positive interactions between electric vehicles and renewable energy sources in CO2-reduced energy scenarios: The Italian case," Energy, vol. 161, pp. 172-182, 2018.

[5] M. Schröder, Z. Abdin, and W. Mérida, "Optimization of distributed energy resources for electric vehicle charging and fuel cell vehicle refueling," Applied Energy, vol. 277, p. 115562, 2020 .

[6] M. Dixit, P. Kundu, and H. R. Jariwala, "Optimal placement of photo-voltaic array and electric vehicles in distribution system under load uncertainty," in 2017 IEEE Power \& Energy Society General Meeting, 2017, pp. 1-5.

[7] S. Singh, P. Chauhan, and N. Singh, "Capacity optimization of grid connected solar/fuel cell energy system using hybrid ABC-PSO algorithm," International Journal of Hydrogen Energy, vol. 45, pp. 10070-10088, 2020. 
[8] A. L. Bukar, C. W. Tan, L. K. Yiew, R. Ayop, and W.-S. Tan, "A rule-based energy management scheme for long-term optimal capacity planning of grid-independent microgrid optimized by multi-objective grasshopper optimization algorithm," Energy conversion and management, vol. 221, p. 113161, 2020.

[9] A. M. Pavan, V. Lughi, and M. Scorrano, "Total cost of ownership of electric vehicles using energy from a renewable-based microgrid," in 2019 IEEE Milan PowerTech, 2019, pp. 1-6.

\section{[10] F. AHMAD, "ANALYSIS OF MICROGRIDS FOR PLUG-IN HYBRID ELECTRIC VEHICLES CHARGING STATIONS," ALIGARH MUSLIM UNIVERSITY ALIGARH, 2019.}

[11] M. R. Mozafar, M. H. Moradi, and M. H. Amini, "A simultaneous approach for optimal allocation of renewable energy sources and electric vehicle charging stations in smart grids based on improved GA-PSO algorithm," Sustainable cities and society, vol. 32, pp. 627-637, 2017.

[12] A. Jafari, T. Khalili, H. G. Ganjehlou, and A. Bidram, "Optimal integration of renewable energy sources, diesel generators, and demand response program from pollution, financial, and reliability viewpoints: A multi-objective approach," Journal of cleaner production, vol. 247, p. 119100 , 2020.

[13] M. Ghiasi, "Detailed study, multi-objective optimization, and design of an AC-DC smart microgrid with hybrid renewable energy resources," Energy, vol. 169, pp. 496-507, 2019.

[14] M. Sedighizadeh, M. Esmaili, and N. Mohammadkhani, "Stochastic multi-objective energy management in residential microgrids with combined cooling, heating, and power units considering battery energy storage systems and plug-in hybrid electric vehicles," Journal of Cleaner Production, vol. 195, pp. 301-317, 2018.

[15] M. Das, M. A. K. Singh, and A. Biswas, "Techno-economic optimization of an off-grid hybrid renewable energy system using metaheuristic optimization approaches-case of a radio transmitter station in India," Energy conversion and management, vol. 185, pp. 339-352, 2019.

[16] G. Badea, R.-A. Felseghi, M. Varlam, C. Filote, M. Culcer, M. Iliescu, et al., "Design and simulation of romanian solar energy charging station for electric vehicles," Energies, vol. 12, p. 74, 2019.

[17] M. Shepero, J. Munkhammar, J. Widén, J. D. Bishop, and T. Boström, "Modeling of photovoltaic power generation and electric vehicles charging on city-scale: A review," Renewable and
Sustainable Energy Reviews, vol. 89, pp. 61-71, 2018.

[18] S. Faddel, A. A. Mohamed, and O. A. Mohammed, "Fuzzy logic-based autonomous controller for electric vehicles charging under different conditions in residential distribution systems," Electric Power Systems Research, vol. 148, pp. 48-58, 2017.

[19] A. R. Bhatti and Z. Salam, "A rule-based energy management scheme for uninterrupted electric vehicles charging at constant price using photovoltaic-grid system," Renewable energy, vol. 125, pp. 384-400, 2018.

[20] K. Araki, L. Ji, G. Kelly, and M. Yamaguchi, "To do list for research and development and international standardization to achieve the goal of running a majority of electric vehicles on solar energy," ed: Multidisciplinary Digital Publishing Institute, 2018.

[21] H. Mehrjerdi and E. Rakhshani, "Vehicleto-grid technology for cost reduction and uncertainty management integrated with solar power," Journal of Cleaner Production, vol. 229, pp. 463-469, 2019.

[22] F. Mohammadi, "Design, analysis, and electrification of a solar-powered electric vehicle," Journal of Solar Energy Research, vol. 3, pp. 293299, 2018

[23] F. J. Ruiz-Rodríguez, J. C. Hernández, and F. Jurado, "Probabilistic load-flow analysis of biomass-fuelled gas engines with electrical vehicles in distribution systems," Energies, vol. 10, p. 1536, 2017.

[24] S. Lasisi, U. Inyang-Udoh, O. T. Olakoyejo, E. O. Ogedengbe, O. G. Awosanya, and S. M. Abolarin, "Operational Classification of Torrefied Biomass in a Gasifier as an Alternative Source of Electricity for EV Charging Station," in AIAA Propulsion and Energy 2020 Forum, 2020, p. 3663.

[25] N. R. Baral, Z. D. Asher, D. Trinko, E. Sproul, C. Quiroz-Arita, J. C. Quinn, et al., "Biomass feedstock transport using fuel cell and battery electric trucks improves lifecycle metrics of biofuel sustainability and economy," Journal of Cleaner Production, vol. 279, p. 123593, 2021.

[26] A. Betancourt-Torcat, T. Poddar, and A. Almansoori, "A realistic framework to a greener supply chain for electric vehicles," International Journal of Energy Research, vol. 43, pp. 2369-2390, 2019.

[27] M. Umar, X. Ji, D. Kirikkaleli, and A. A. Alola, "The imperativeness of environmental quality in the United States transportation sector amidst 
biomass-fossil energy consumption and growth," Journal of Cleaner Production, vol. 285, p. 124863, 2021.

[28] H. Das, M. Rahman, S. Li, and C. Tan, "Electric vehicles standards, charging infrastructure, and impact on grid integration: A technological review," Renewable and Sustainable Energy Reviews, vol. 120, p. 109618, 2020.

[29] S. Ghosh and V. Karar, "Assimilation of optimal sized hybrid photovoltaic-biomass system by dragonfly algorithm with grid," Energies, vol. 11, p. $1892,2018$.

[30] M. Dixit, "Impact of optimal integration of renewable energy sources and electric vehicles in practical distribution feeder with uncertain load demand," International Transactions on Electrical Energy Systems, vol. 30, p. e12668, 2020.

[31] B. Sun, "A multi-objective optimization model for fast electric vehicle charging stations with wind, PV power and energy storage," Journal of Cleaner Production, vol. 288, p. 125564, 2021. 